\title{
Diversity patterns of Middle Permian gastropod assemblages from the Tak Fa Formation, Central Thailand
}

\author{
Chatchalerm Ketwetsuriya ${ }^{1,2}$ (D) $\cdot$ Imelda M. Hausmann ${ }^{1,2} \cdot$ Alexander Nützel $^{1,2,3}$
}

Received: 13 March 2020 / Revised: 31 May 2020 / Accepted: 18 January 2021 / Published online: 7 May 2021

(C) The Author(s) 2021

\begin{abstract}
Middle Permian marine invertebrate assemblages from Central Thailand are strongly dominated by gastropods. Two gastropod assemblages from the Tak Fa Limestone at Khao Noi and Khao Chao Thong of the Nakhon Sawan area are the first Permian ones from Thailand that are analysed regarding diversity and composition based on quantitative data. Both gastropod assemblages, comprising 40 species in total, are dominated by the gastropods Anomphalus sp., Warthia $\mathrm{cf}$. brevisinuata and Glabrocingulum magnum; the genus Anomphalus is especially abundant which is unusual for Permian assemblages. Both studied gastropod assemblages have a similar taxonomic composition and diversity including the same values of diversity indices that indicate a moderate diversity. In addition, rarefaction analyses and rank-abundance distributions also suggest that diversity and structure of both assemblages are the same. The studied assemblage is compared with other Permian gastropod assemblages from Asia (Malaysia, East Timor and Japan). Rarefaction, diversity indices and rank-abundance distributions suggest that the diversity of the studied fauna is distinctly lower than that of the others despite coming from similar depositional environments. This is surprising because the Tak Fa gastropods lived at lower latitudes than the others. This could suggest an inverse diversity gradient in the Palaeo-Tethys, but more evidence is needed to substantiate this assumption. Several Late Palaeozoic and Early Mesozoic fossil assemblages are dominated by gastropods, e.g. those from the Pennsylvanian Buckhorn Asphalt deposit, the Permian from Japan and Malaysia, as well as the Late Triassic Cassian Formation. This shows that at least locally, gastropod dominance is not restricted to modern faunas.
\end{abstract}

Keywords Gastropoda $\cdot$ Permian $\cdot$ Thailand $\cdot$ Tak Fa Formation $\cdot$ Diversity

\section{Introduction}

In the last years, several new Permian gastropod faunas from Thailand were discovered (Ketwetsuriya et al. 2014, 2016, 2020a, 2020b). Virtually nothing had been known about Permian gastropods from Thailand before. The most diverse of these gastropod faunas is that from the Tak Fa Formation

Chatchalerm Ketwetsuriya

ketwetsuriya.c@gmail.com

1 Department of Earth and Environmental Sciences, Palaeontology \& Geobiology, Ludwig-Maximilians-Universität München, Richard-Wagner-Str. 10, 80333 München, Germany

2 SNSB-Bayerische Staatssammlung für Paläontologie und Geologie, Richard-Wagner-Str. 10, 80333 München, Germany

3 GeoBio-Center, Ludwig-Maximilians-Universität München, Richard-Wagner-Str. 10, 80333 München, Germany
(Ketwetsuriya et al. 2014, 2016). This silicified invertebrate fauna is strongly dominated by gastropods. It was retrieved by bulk sampling and etching from the calcareous rocks, and therefore this collection is quantitative. This offers the possibility of a meaningful comparison, regarding its diversity and composition, with other gastropod faunas from Southeast Asia, for which relative abundances are known. The analysed assemblages of the Tak Fa Formation come from two localities in the Nakhon Sawan Province, Central Thailand: (1) Khao Noi hill, this fauna has been monographed by Ketwetsuriya et al. (2016), and (2) a newly retrieved assemblage from Khao Chai Thong hill. Both localities are $2 \mathrm{~km}$ apart (Fig. 1) and have a similar species composition. However, relative abundances differ. The aim of this contribution is to expand the understanding of Permian gastropod diversity of Thailand and adjacent areas by comparing the quantitative data set of the two localities of the Tak Fa Formation at Khao Noi hill and Khao Chai Thong hill. This study also presents a detailed quantitative analysis of 


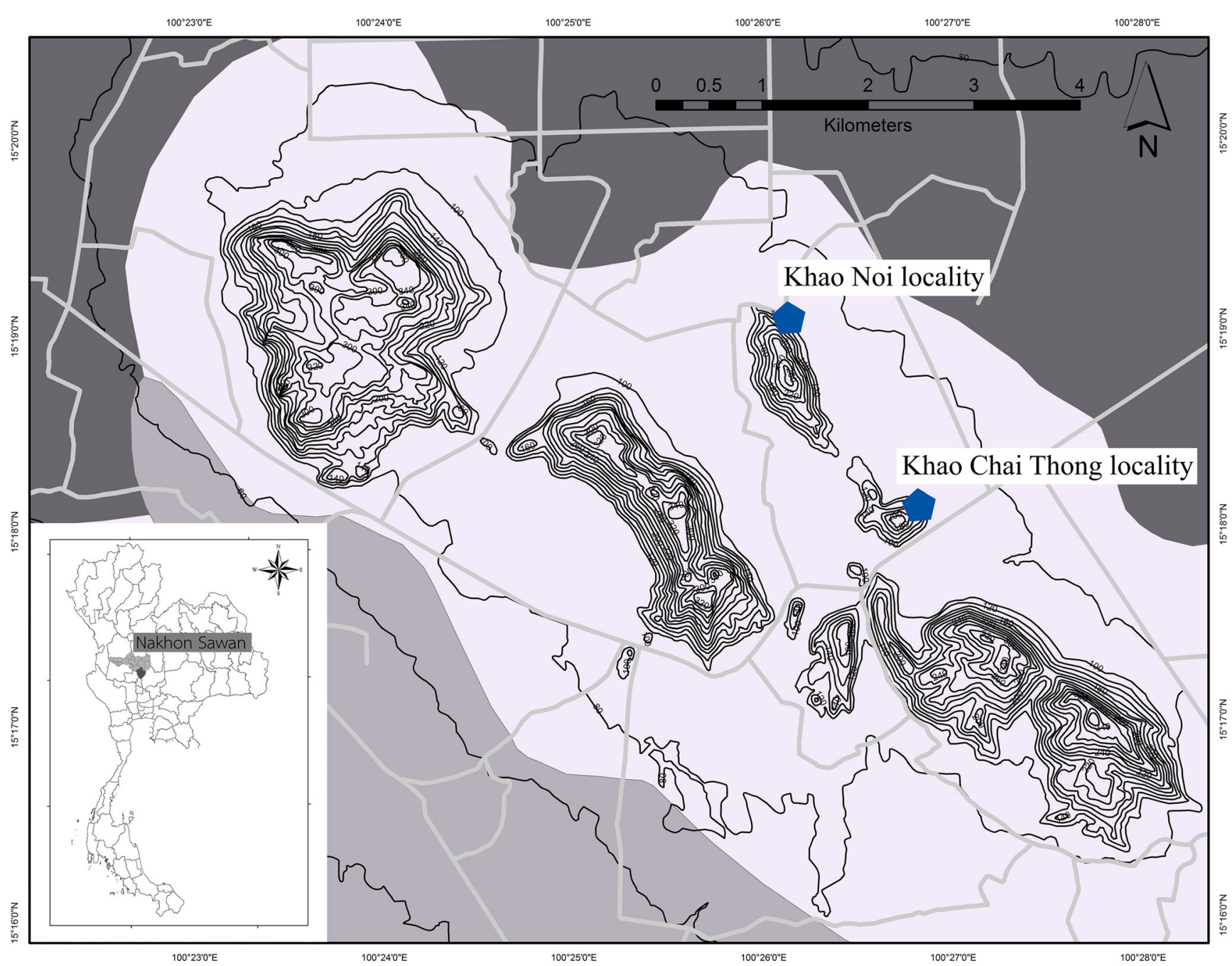

Fig. 1 Geological map of the study area showing the positions of the studied samples at Khao Noi hill $\left(15^{\circ} 18^{\prime} 50^{\prime \prime} \mathrm{N}, 100^{\circ} 26^{\prime} 10^{\prime \prime} \mathrm{E}\right)$ and Khao Chai Thong hill ( $15^{\circ} 17^{\prime} 59^{\prime \prime} \mathrm{N}, 100^{\circ} 26^{\prime} 51^{\prime \prime}$ E), Tak Fa District, Nakhon Sawan Province, Central Thailand. Contour lines are indicated in metres

gastropod diversity, which is the most abundant group in the studied samples using diversity indices, rarefaction analysis and rank-abundance distributions. The studied Permian gastropod assemblage from Thailand is compared by means of diversity to other gastropod faunas from Asia for which quantitative data were published, for instance, to the Permian gastropod fauna from Perak, Malaysia, East Timor, and the Akasaka Limestone, Japan, to enhance our knowledge on the Permian gastropod diversity and palaeobiogeography.

The Tak Fa Formation consists of shallow water carbonate deposits (fusulinid limestones) and crops out along the western margin of the Indochina Terrane (Wielchowsky and Young 1985; Metcalfe and Sone 2008) in the Phetchabun Province, Lop Buri Province and Nakhon Sawan Province, Central Thailand. It yields one of the most extensively studied Permian marine invertebrate faunas of Thailand. Gastropods are one of its most important components. However, until recently, the
Permian gastropod fauna from Thailand has hardly been studied. The presence of gastropods was just mentioned in treatments of other groups, e.g. brachiopods (Grant 1976; Waterhouse 1982; Sone 2010). Recently, Ketwetsuriya et al. $(2014,2016)$ produced the first systematic study on the Middle Permian gastropod fauna from the Tak Fa Formation, Nakhon Sawan Province, Central Thailand. Gastropods comprise $72.7 \%$ of the species and $88.4 \%$ of the specimens in the analysed samples (excluding fusulinids which are highly abundant). Around 40 species gastropod faunas were reported, 17 nominate species and 23 species in open nomenclature, with one new genus and twelve new species. However, a quantitative census of Permian gastropods from Thailand and also from Southeast Asia has rarely been reported (from Perak, Malaysia: Batten 1972, 1979, 1985 and from East Timor: Wanner 1941). An investigation of Permian gastropod diversity facilitates a better understanding of the regional palaeobiogeography of this region. 


\section{Location and geological setting}

The studied gastropod assemblages come from two isolated limestone hills, Khao Noi hill $\left(15^{\circ} 18^{\prime} 50^{\prime \prime} \mathrm{N}, 100^{\circ} 26^{\prime}\right.$ $\left.10^{\prime \prime} \mathrm{E}\right)$ and Khao Chai Thong hill $\left(15^{\circ} 17^{\prime} 59^{\prime \prime} \mathrm{N}, 100^{\circ} 26^{\prime}\right.$ $51^{\prime \prime}$ E) in Tak Fa District, Nakhon Sawan Province, Central Thailand, forming part of a hill chain, which extends for approximately $6 \mathrm{~km}$ in northwest-southeast direction, and is surrounded by unconsolidated Quaternary alluvial deposits at an average elevation of $300 \mathrm{~m}$ above mean sea level (Fig. 1). The distance between the two sampling spots is approximately $2 \mathrm{~km}$. The fauna from Khao Noi was treated systematically by Ketwetsuriya et al. (2016) who also provided data about diversity and relative abundances. The fauna from the second sampling spot (Khao Chai Thong) was retrieved later and had not been included in the mentioned monograph.

The limestone deposits in the study area are assigned to the Tak Fa Formation (informally known as Tak Fa Limestone), which is a part of Saraburi Group (Nakornsri 1976, 1981). The Tak Fa Formation is distributed over the Phetchabun, Lop Buri and Nakhon Sawan provinces (Nakornsri 1976) and consists mainly of bedded fossiliferous limestones, massive limestones and subordinate siliciclastic rocks (Yanagida 1988). The marine invertebrate fauna of the Tak Fa Limestone has been studied by various authors, and comprises fusulinid foraminifers (Pitakpaivan 1965; Igo 1972, 1992), brachiopods (Yanagida 1988; Sone et al. 2009), conodonts (Metcalfe and Sone 2008; Chitnarin et al. 2012, 2017), corals (Yanagida 1988), calcareous algae (Fontaine et al. 1999), bryozoans (Sakagami 1975, 1999) and gastropods (Ketwetsuriya et al. 2014, 2016). The unit formed during the Early to late Middle Permian (Chonglakmani and Fontaine 1992; Igo 1992) and has its type area at Tak Fa in southeastern Nakhon Sawan Province. During the Permian, the area in which the Tak Fa Formation is exposed was situated in the Palaeo-Tethys, at an equatorial position in the Equatorial Warm Water Province (Metcalfe and Sone 2008)

The age estimates of the Tak Fa Formation range from the latest Carboniferous to Middle or late Middle Permian (Ueno and Charoentitirat 2011), based on biostratigraphy (e.g. fusulinid foraminifers, conodonts, brachiopods and bryozoans). The age of the Tak Fa Formation of the study area is based on the fusulinid foraminifers Verbeekina verbeeki and Parafusulina sp., which indicate a Middle Permian age (Middle Wordian to Middle Capitanian) (Napradit 2005; Jaiboon 2001). Chitnarin et al. (2012) noted that the Ta khli section of the Tak Fa Limestone in Nakhon Sawan and Lopburi provinces, which is related to the studied localities, has a Middle Permian (Wordian) age based on fusulinid foraminifers. Chitnarin et al. (2017) re-assigned this section to the Early Permian (Artinskian) due to the discovery of the fusulinid foraminifers Pamirina sp. and Pseudofusulina sp.

\section{Materials and methods}

The limestone samples were taken by the first author in 2010, 2013 and 2015 where weathered silicified gastropods were visible on the surface of the carbonate rock (Fig. 2) on two isolated limestone hills (Khao Noi and Khao Chai Thong) in Tak Fa District, Nakhon Sawan Province, Central Thailand (Fig. 1). The limestone block samples (approximately $100 \mathrm{~kg}$ ) were dissolved in formic acid at the Bayerische Staatssammlung für Paläontologie und Geologie in Munich, Germany. After dissolving, the residue was wet sieved at a mesh size of $0.5 \mathrm{~mm}$. All determinable fossils were picked from the washed residues. Most fossil material consists of fragmented shell hash, but more or less complete specimens were also present. Gastropods were classified at species-level in the course of taxonomic study by Ketwetsuriya et al. (2016). The specimens of each species were counted, including other fossils, e.g. bivalves, brachiopods and algae. Rarefaction analyses and calculation of diversity indices (Shannon-Wiener and Simpson) were performed using the PAST software package (Hammer et al. 2001). Rankabundance distributions and model fit were calculated in $\mathrm{R}(\mathrm{R}$ Core Team 2017) using the packages vegan (Oksanen et al. 2018) and sads (Prado et al. 2018). For the diversity analysis, fusulinids were excluded.

The majority of the fossil material is housed in the Bayerische Staatssammlung für Paläontologie und Geologie (Bavarian State Collection for Palaeontology and Geology) in Munich, Germany (SNSB-BSPG 2014 XI). Some specimens are housed in the Chulalongkorn University, Museum of Zoology, Bangkok, Thailand (CUMZ).

\section{Results}

The samples from the Tak Fa Formation produced a rich silicified fossil assemblage. Besides a high amount of unidentifiable shell fragments, the washed residues yielded gastropod shells, fusulinids, bryozoan fragments, sponge spicules, bivalve shells and brachiopods. Due to the coarse silicification and fragmentation, not all fossils could be determined at species level. Molluscs, especially gastropods, are the most abundant and diverse group in both fossil assemblages, yielding $72.7 \%$ of the species and $88.4 \%$ of the specimens. The strong dominance of gastropods in terms of species richness and abundance is remarkable, but it must be taken into account that gastropod-rich rocks were sampled preferentially in the field. 
Fig. 2 Field photographs. a Fossiliferous limestone from the middle part of Khao Noi hill predominately containing gastropods. b Fossiliferous limestone from Khao Chai Thong hill yielding mainly gastropod fragments
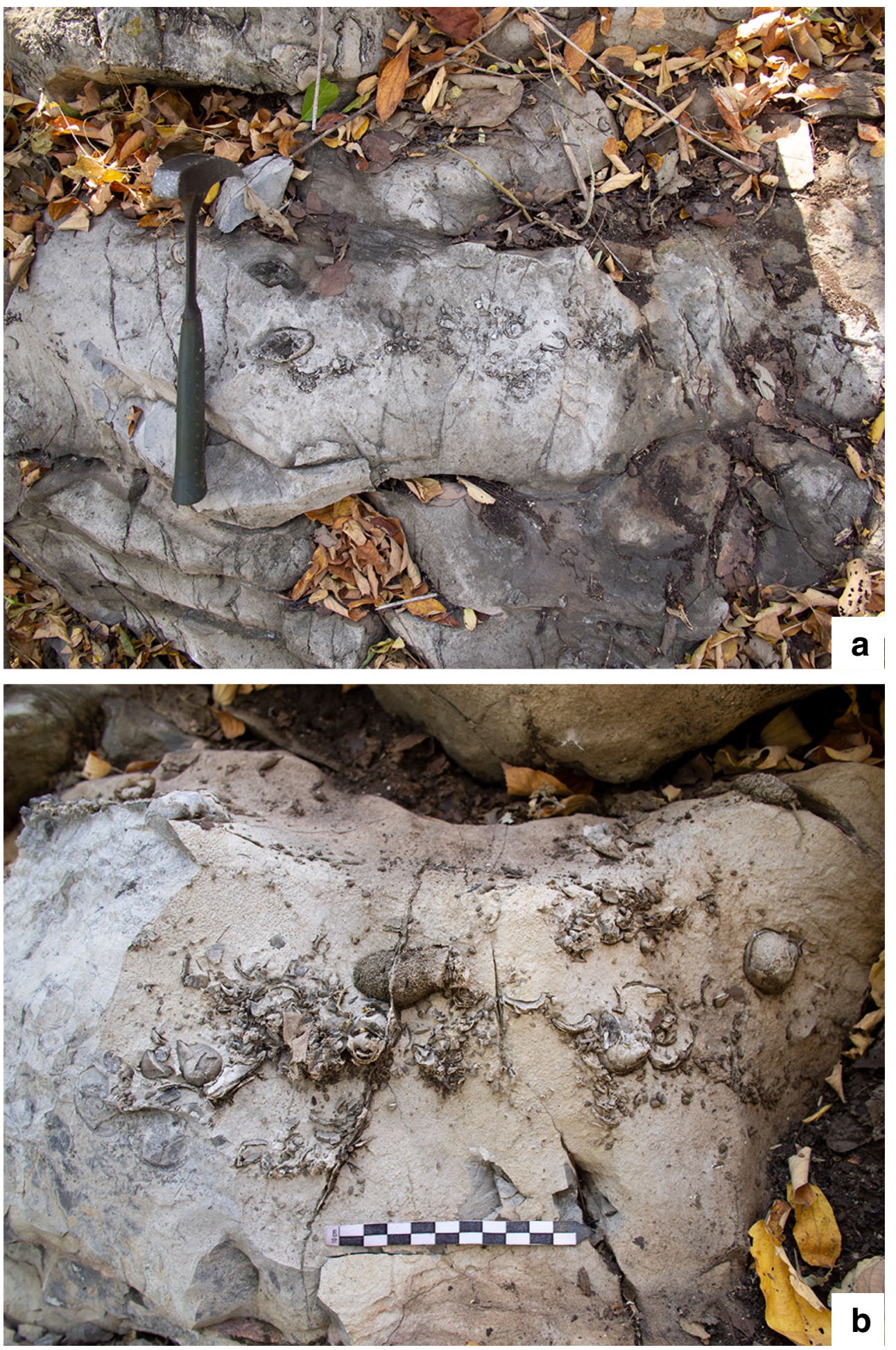

\section{Gastropod fauna of the studied samples}

Taxonomic composition

The gastropod assemblage from Khao Noi comprises 579 specimens which represent 40 species (Fig. 3), i.e. 17 nominate species and 23 species in open nomenclature. At the species level, the vetigastropod Anomphalus sp. is the most abundant species (34.1\%), followed by the bellerophontid Warthia cf. brevisinuata (8.7\%), eotomariid Glabrocingulum magnum (8.0\%) and the high-spired orthonematid Protostylus sp. (7.6\%).

In comparison, the gastropod assemblage from Khao Chai Thong yielded 402 specimens representing 34 species, i.e. 14 nominate species and 20 species in open nomenclature. The three 


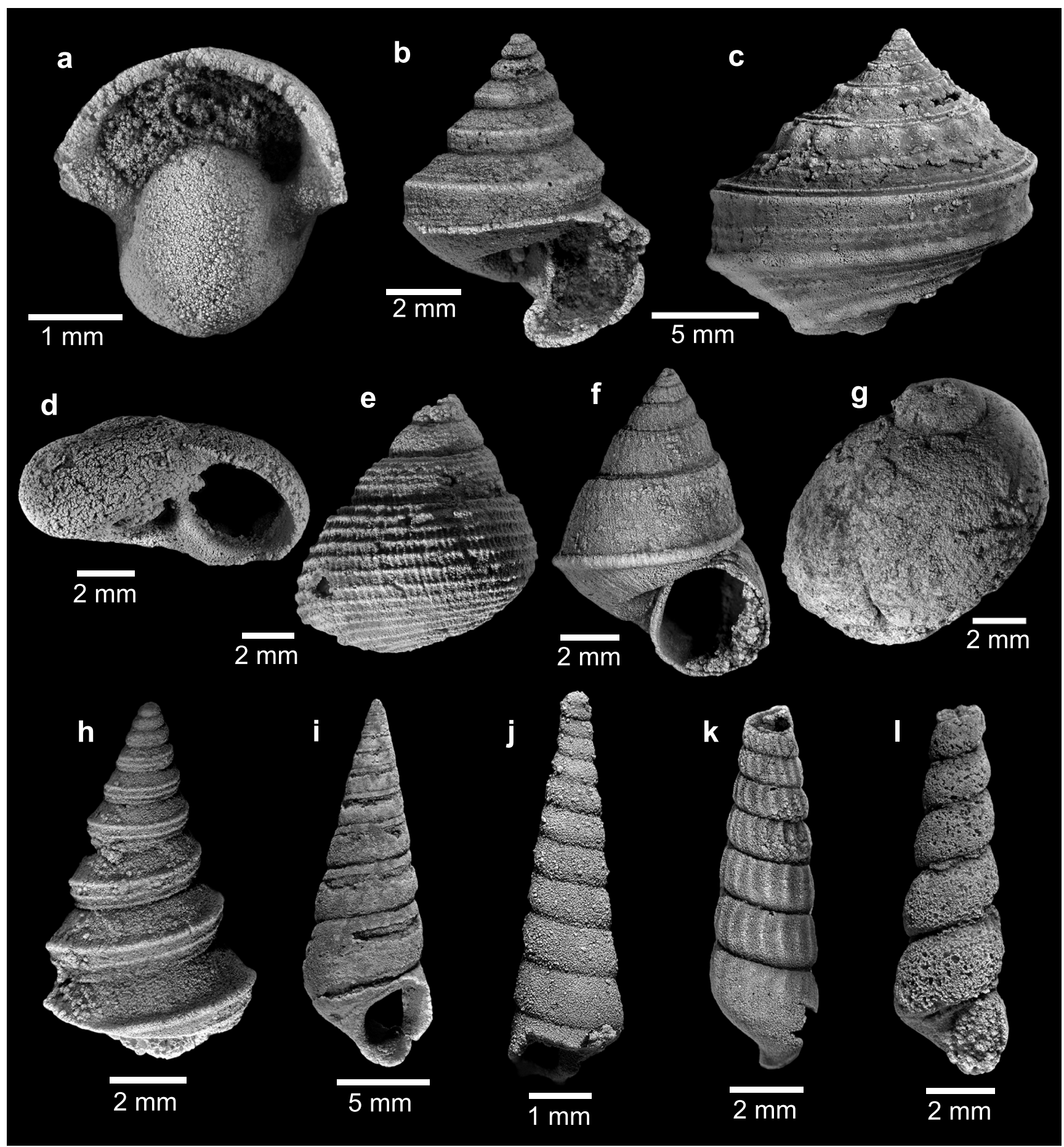

Fig. 3 The twelve most abundant gastropod species from the Tak Fa Limestone at Nakhon Sawan area; a Bellerophontoidean, Warthia cf. brevisinuata Waagen, 1880, SNSB-BSPG 2014 XI 2. b-f Vetigastropoda, b Baylea? umbilicata Nützel and Ketwetsuriya, 2016 in Ketwetsuriya et al. (2016), SNSB-BSPG 2014 XI 13. c Glabrocingulum thailandensis Nützel and Ketwetsuriya, 2016 in Ketwetsuriya et al. (2016), SNSB-BSPG 2014 XI 48. d Anomphalus sp., SNSB-BSPG 2014 XI 28. e Yunnania pulchra Nützel and Ketwetsuriya, 2016 in
Ketwetsuriya et al. (2016), SNSB-BSPG 2014 XI 34. f Microdoma carinata Nützel and Ketwetsuriya 2016, SNSB-BSPG 2014 XI 47. g Neritimorpha, Naticopsis sp., SNSB-BSPG 2014 XI 95. h-k Caenogastropoda, h Goniasma tricarinata Nützel and Ketwetsuriya 2016, SNSB-BSPG 2014 XI 45. i Protostylus sp., SNSB-BSPG 2014 XI 56. j Cambodgia acuminate Nützel and Ketwetsuriya 2016, SNSBBSPG 2014 XI 117. k Trepsipleura chordanodosa Kues 2002, SNSBBSPG 2014 XI 1. I Streptacis? sp., SNSB-BSPG 2014 XI 51 
most abundant species are the same as in the Khao Noi assemblage. Anomphalus sp. (32.5\%) is the most abundant species again, followed by Warthia cf. brevisinuata (7.2\%). Glabrocingulum magnum and meekospirid Cambodgia acuminata are equally abundant with $6.0 \%$ each, as are naticopsid Naticopsis spp. and microdomatid Microdoma carinata dealing with $4.7 \%$ each. Six taxa from the Khao Noi assemblage were not observed in the Khao Chai Thong assemblage; these are, in descending order, the euphemitid Euphemites graffhami $(0.5 \%)$, the trochonematid Knightinella ornata $(0.5 \%)$, the bellerophontid Khumerspira thailandensis $(0.3 \%)$, the trochonematid Amaurotoma? sp. (0.3\%), the soleniscid
Table 1 Species and their abundances of the studied gastropod assemblages, Khao Noi hill and Khao Chai Thong hill, from the Tak Fa Limestone, Nakhon Sawan

\begin{tabular}{|c|c|c|c|}
\hline \multirow[t]{2}{*}{ Groups } & \multirow[t]{2}{*}{ Species } & \multicolumn{2}{|c|}{ Number of specimens } \\
\hline & & Khao Noi & Khao Chai tong \\
\hline \multirow[t]{8}{*}{ Bellerophontoidean } & Euphemites graffhami & 3 & 0 \\
\hline & Warthia cf. brevisinuata & 50 & 29 \\
\hline & Warthia sp. & 12 & 4 \\
\hline & Bellerophon sp. & 5 & 4 \\
\hline & Bellerophon? sp. & 2 & 6 \\
\hline & Pharkidonotus khaonoiensis & 11 & 8 \\
\hline & Khumerspira thailandensis & 2 & 0 \\
\hline & Retispira lyelli & 5 & 2 \\
\hline \multirow[t]{3}{*}{ Euomphalina } & Discotropis? sp. & 1 & 1 \\
\hline & Euomphalus? sp. & 1 & 1 \\
\hline & Euomphalid & 5 & 7 \\
\hline \multirow[t]{13}{*}{ Vetigastropoda } & Baylea? umbilicata & 14 & 11 \\
\hline & Knightinella ornata & 3 & 0 \\
\hline & Knightinella sp. & 2 & 3 \\
\hline & Amaurotoma? sp. & 2 & 0 \\
\hline & Takfaia kuesi & 7 & 9 \\
\hline & Glabrocingulum magnum & 46 & 24 \\
\hline & Anomphalus lateumbilicatus & 2 & 5 \\
\hline & Anomphalus sp. & 197 & 131 \\
\hline & Yunnania pulchra & 12 & 15 \\
\hline & Anticonulus? sp. & 3 & 1 \\
\hline & Coeloconulus panae & 1 & 1 \\
\hline & Eocalliostoma sp. & 6 & 2 \\
\hline & Microdoma carinata & 10 & 19 \\
\hline \multirow[t]{2}{*}{ Neritimorpha } & Naticopsis spp. & 14 & 19 \\
\hline & Trachydomia takhliensis & 9 & 1 \\
\hline \multirow[t]{13}{*}{ Caenogastropoda } & Goniasma tricarinata & 22 & 14 \\
\hline & Stegocoelia sp. 1 & 5 & 1 \\
\hline & Stegocoelia sp. 2 & 5 & 7 \\
\hline & Orthonema sp. & 2 & 2 \\
\hline & Protostylus sp. & 44 & 17 \\
\hline & Soleniscus sp. & 5 & 5 \\
\hline & Strobeus sp. & 1 & 2 \\
\hline & Cylindritopsis spheroides & 1 & 0 \\
\hline & Meekospira sp. & 5 & 8 \\
\hline & Ceraunocochlis sp. & 1 & 0 \\
\hline & Cambodgia acuminata & 20 & 24 \\
\hline & Trepsipleura chordanodosa & 21 & 7 \\
\hline & Pseudozygopleura? sp. & 1 & 1 \\
\hline Heterobranchia & Streptacis? sp. & 21 & 11 \\
\hline
\end{tabular}


Table 2 Model fit for rank-abundance distributions of the Tak Fa assemblages. Best model fit is shown in bold

\begin{tabular}{lll}
\hline Tak Fa assemblages & Models & AIC \\
\hline Khao Noi & Brokenstick & 413.15 \\
& Preemption & 334.06 \\
& Lognormal & $\mathbf{1 8 1 . 2 1}$ \\
& Zipf & 181.39 \\
Khao Chai Thong & Zipf-Mandelbrot & 183.39 \\
& Brokenstick & 243.67 \\
& Preemption & 237.82 \\
& Lognormal & $\mathbf{1 5 7 . 8 3}$ \\
& Zipf & 163.88 \\
& Zipf-Mandelbrot & 165.88 \\
\hline
\end{tabular}

Cylindritopsis spheroides $(0.2 \%)$ and the meekospirid Ceraunocochlis sp. $(0.2 \%)$. These taxa are rare at Khao Noi. Almost half of the total number of gastropod species is only represented by one to three specimens. All species of two gastropod assemblages and their abundances are listed in Table 1.

\section{Diversity}

The diversity of both gastropod assemblages is practically the same. The Simpson indices of the Khao Noi (0.86) and Khao Chai Thong samples $(0.87)$ are identical when considering the relative error intervals. The Shannon-Wiener Index is 2.7 for both assemblages, indicating a moderate diversity.

Rank-abundance distributions confirm these results. The shape of the Khao Noi and Khao Chai Thong distributions is almost the same (Fig. 4). When trying to fit models to both rank-abundance distributions, a lognormal model fits best to both assemblages (Table 2). However, AIC (Akaike Information Criterion) values indicate that the gastropod assemblage from Khao Noi also fits well to the Zipf model, since the values are almost identical (lognormal 181.21 vs. Zipf 181.39). Both assemblages have a similar diversity and ecological complexity. The evenness is moderate as is indicated by the chosen model (e.g. Magurran 2004).

Rarefaction analysis suggests that the sample sizes of the gastropod assemblages from Khao Noi and Khao Chai Thong are sufficient to estimate diversity, because the rarefaction curves are saturated at approximately 400 specimens (Fig. 5). The curves further suggest that two assemblages are almost identical regarding diversity. The similarity of both curves as well as the other mentioned diversity metrics suggests a similar original diversity of biota.

In addition, both studied assemblages closely resemble each other in taxonomic composition and relative abundances with the gastropods Anomphalus sp., Warthia cf. brevisinuata and Glabrocingulum magnum being most abundant at both localities, suggesting that they come from the same environmental setting. The similarity both with regard to diversity and composition justifies that these two samples from the Tak Fa Limestone can be pooled to represent a single gastropod assemblage, for further comparisons with other Permian gastropod assemblages from Southeast Asia and adjacent areas.

Diversity in specific gastropod groups

Combined from the two sampling localities, the studied gastropod fauna comprises 981 specimens representing 40 species (Fig. 6), and is clearly dominated by Vetigastropoda (Fig. 7).
Fig. 4 Rank abundance diagram of the two studied Middle Permian gastropod assemblages of the Tak Fa Limestone from Khao Noi hill and Khao Chai Thong hill, Tak Fa District, Nakhon Sawan Province, Central Thailand

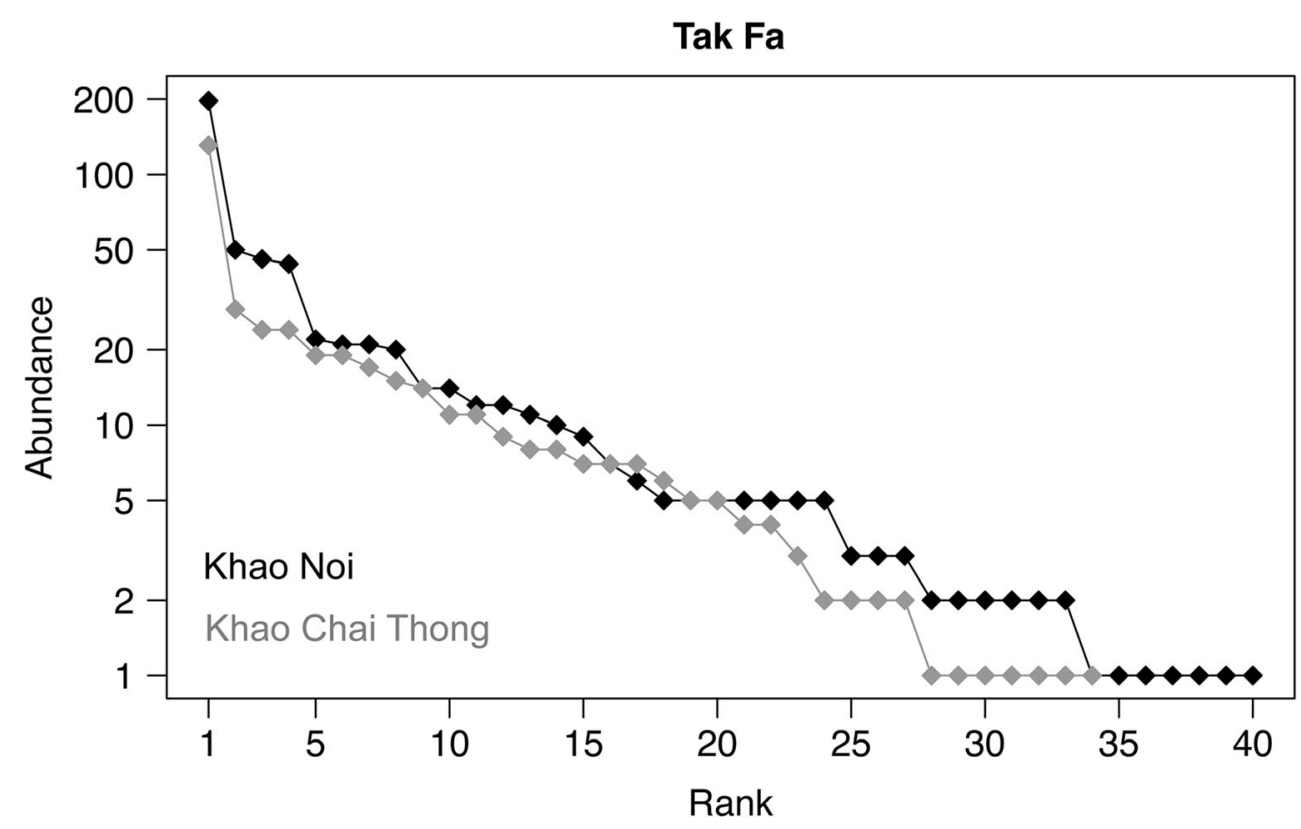


Fig. 5 Rarefaction curves for the two studied Middle Permian gastropod assemblages of the Tak Fa Limestone from Khao Noi hill and Khao Chai Thong hill, Tak Fa District, Nakhon Sawan Province, Central Thailand

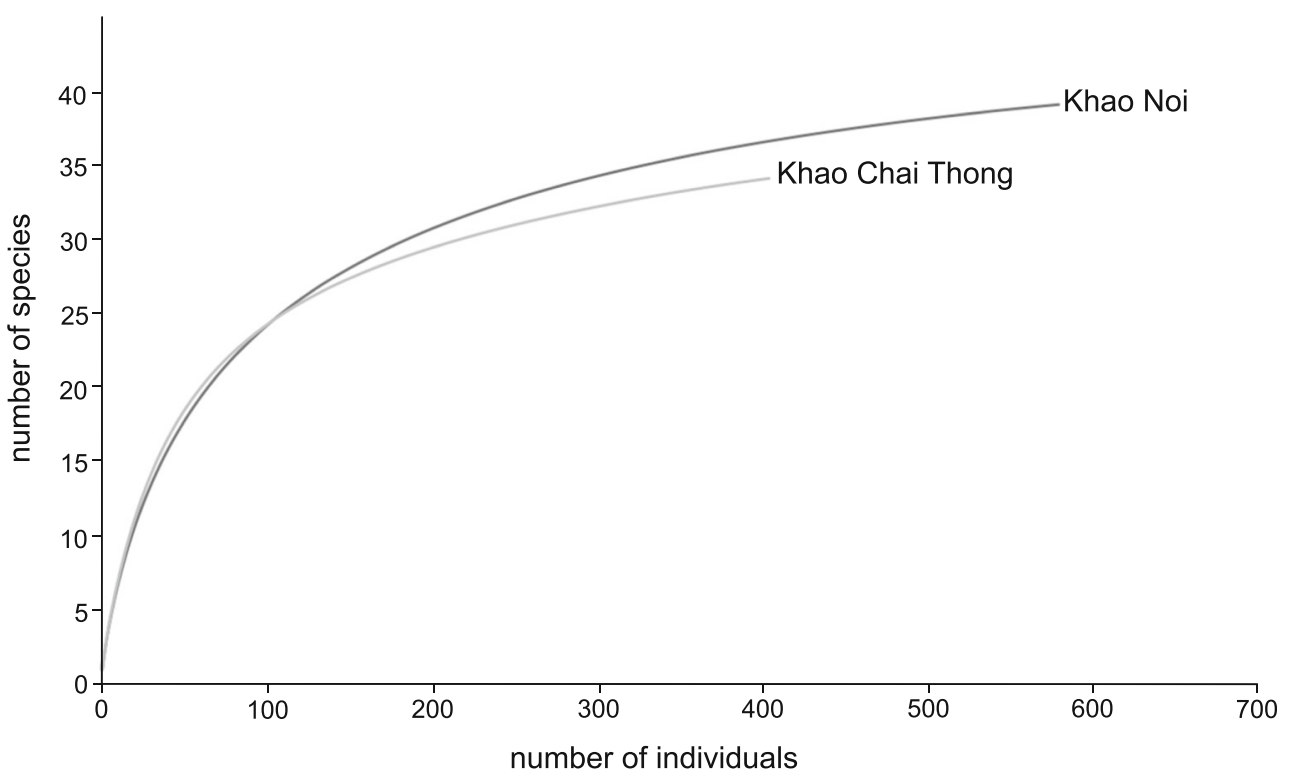

Five hundred twenty-six specimens or $53.6 \%$ of the gastropod specimens belong to the Vetigastropoda, which is also the most diverse group (13 species). Anomphalus sp. is the most abundant species (33.4\%), followed by four "endemic" species, so far only known from the Tak Fa Limestone: Glabrocingulum magnum (7.1\%), Microdoma carinata (3.0\%), Yunnania pulchra (2.8\%) and Baylea? umbilicata $(2.5 \%)$. The high-spired Caenogastropoda are also important and represents the second most abundant group with 221 specimens $(22.5 \%)$.

With 13 species, caenogastropods are as species-rich as Vetigastropoda. Protostylus sp. (6.2\%) is the most abundant caenogastropod, followed by Cambodgia acuminata (4.5\%), Goniasma tricarinata (3.7\%) and Trepsipleura chordanodosa (2.9\%).

The bellerophontoideans are present with 8 species and 143 specimens (14.6\%). Warthia cf. brevisinuata is most abundant in this group ( $8.1 \%$ ), followed by Pharkidonotus khaonoiensis (1.9\%) and Warthia sp. (1.6\%). The typical cosmopolitan genera Bellerophon, Warthia, Euphemites and Retispira are also present in this assemblage. The bellerophontoid species Pharkidonotus khaonoiensis and Khumerspira thailandensis were newly described from this fauna.

Neritimorpha are present with two typical Late Palaeozoic genera with 43 specimens (4.4\%). Of those, Naticopsis is more abundant (3.4\%), followed by Trachydomia takhliensis (1.0\%).

Planispiral shells of Euomphalina are only a minor part of the assemblage, comprising 3 species and 16 specimens $(1.0 \%)$. All species in this group are left in open nomenclature because the specimens are too poorly preserved.

Heterobranchia is represented by a single species, Streptacis? sp., with 32 specimens (3.3\%). However, it must be noted that protoconchs would be needed to diagnose Heterobranchia with certainty, but are not preserved in the studied assemblages.
Accordingly, the generic and higher assignments remain tentative. It should be noted, though, that Streptacis has been commonly reported from Late Palaeozoic deposits.

The significant number of species only known from the Tak Fa Limestone in the analysed assemblages suggests that Permian Palaeo-tethyan gastropod faunas are poorly known and that additional sampling of new fossil sites will result in the finding of new species.

\section{Faunal compositions of the Tak Fa Limestone at Nakhon Sawan area}

The present collection from the two fossil assemblages from the Tak Fa Limestone in the Nakhon Sawan area comprises ca. 1,110 invertebrate fossil specimens and is characterised by a moderate diversity (moderate species richness and moderate evenness). The analysed collections comprise a total of 55 species. The assemblage is strongly dominated by gastropods (Fig. 8), which account for $88.5 \%$ of all specimens (981 gastropod specimens) and 40 species (75.5\% of the species), mostly representing widespread Late Palaeozoic genera such as Warthia, Bellerophon, Glabrocingulum, Anomphalus, Solensicus, Naticopsis and Stegocoelia. The samples also yield three species of bivalves (a small nuculoid bivalve and two indetermined bivalves). Bivalves are the second most diverse group (5.7\%). Articulate brachiopods are represented by two small species accounting for $0.4 \%$ of the number of specimens. One scaphopod specimen and a polyplacophoran plate are present in the studied samples. Calcareous algae contribute $4.7 \%$ of the specimens (fragments) representing two species, a codiaceaen and the dasycladacean Mitzia sp.. The samples also yielded large sclerites probably deriving from 


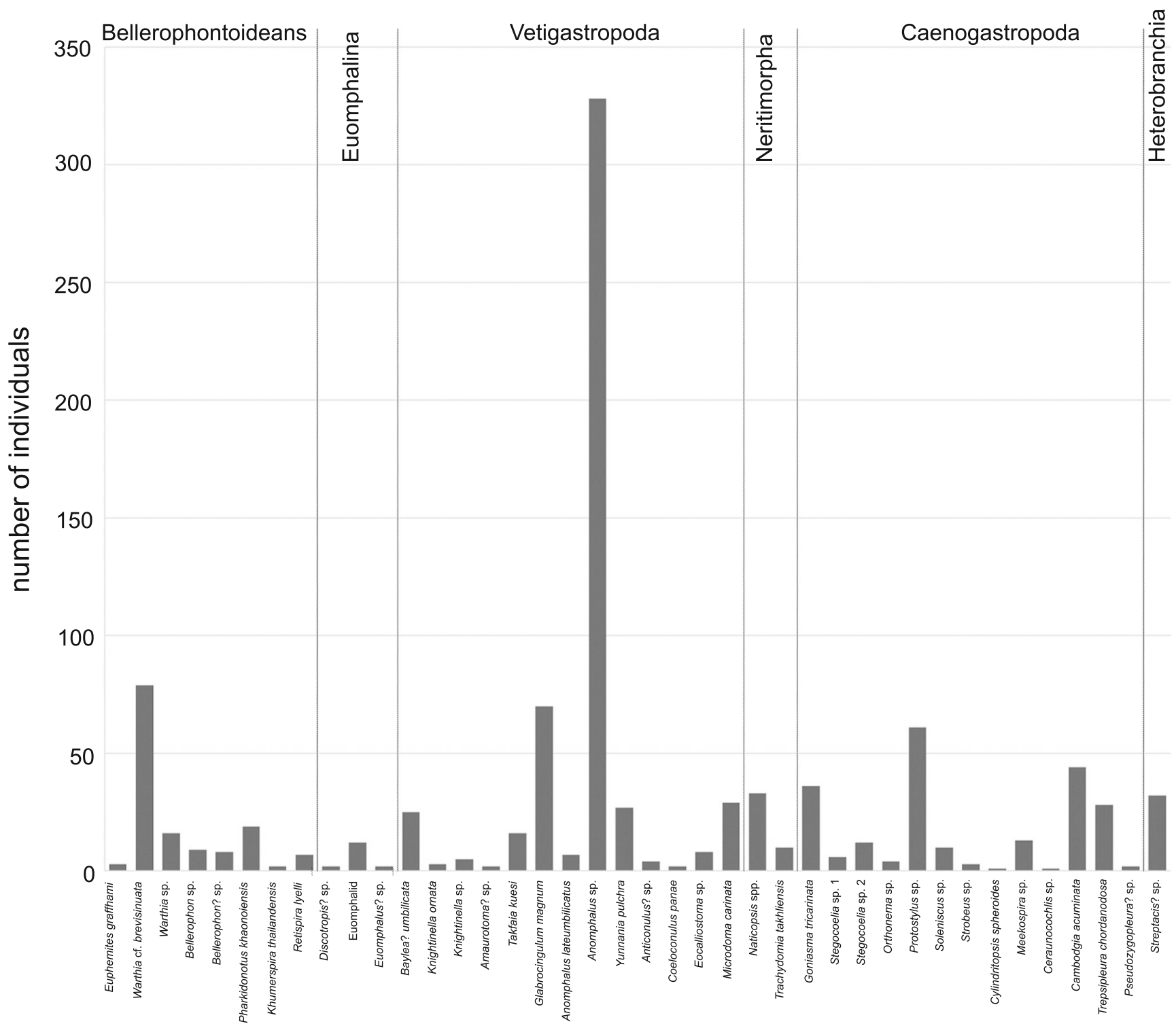

Fig. 6 Distribution of species abundances (number of specimens) showing a strong dominance and diverse of Vetigastropoda and a diverse of Caenogastropoda in the studied gastropod assemblage of the Tak Fa Limestone, Nakhon Sawan

sponges, counted as a single species and specimen for our analyses. Two species of rugose corals, one solitary and one colonial form, are present. In addition, two species of bryozoans and one crinoid species (crinoid ossicles) are present in the samples from both localities.

The presence of conjoined valves of bivalves, ostracods and brachiopods, indicate that the fauna is predominantly autochthonous. Moreover, the presence of the algae and of foraminifera suggests a tropical shallow water environment. Many of the gastropods are strongly fragmented, and the complete shells lie in various directions what may suggest deposition in a high-energy environment. However, the presence of complete large shells and articulated shells of bivalves, brachiopods and ostracods suggests that this assemblage is autochthonous or parautochthonous.

\section{Discussion}

Gastropods are one of the most diverse marine invertebrate groups of the Late Palaeozoic. They were also widespread in the tropical carbonate platforms in the Palaeo-Thethys. However, quantitative analyses of the Permian gastropods from East and Southeast Asia have never been conducted, and few data sets providing relative abundances have been published so far, i.e. from only four areas: Malaysia, East Timor, Japan and the studied gastropod assemblage from Thailand.

When we started our study of Permian gastropods from Thailand, a single nominate gastropod species had been known: Magnicapitatus huazhangae Sone 2010. Meanwhile 
Fig. 7 Pie chart of gastropod group composition showing the high abundance of

Vetigastropoda in the studied gastropod assemblage of the Tak Fa Limestone, Nakhon Sawan

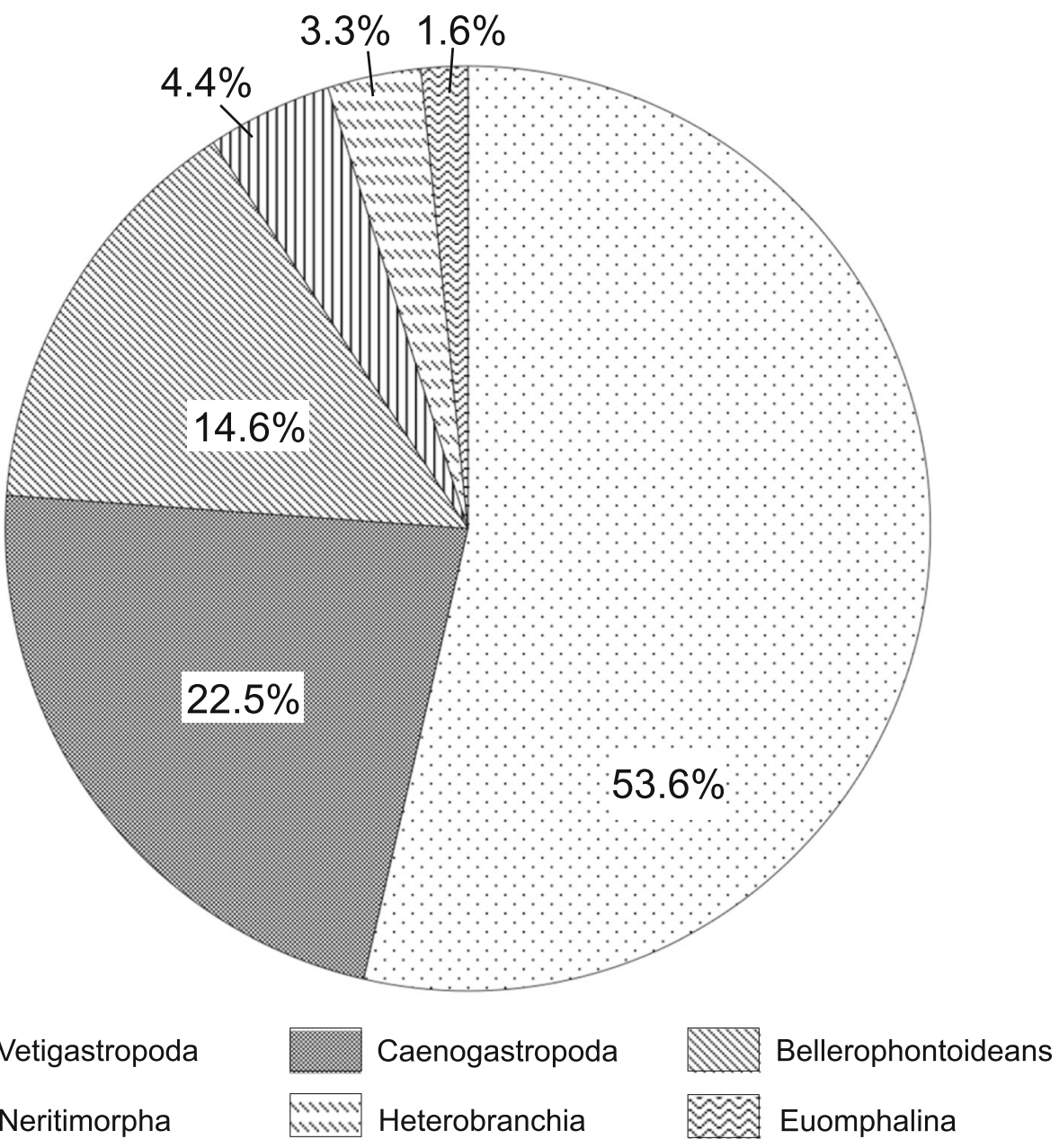

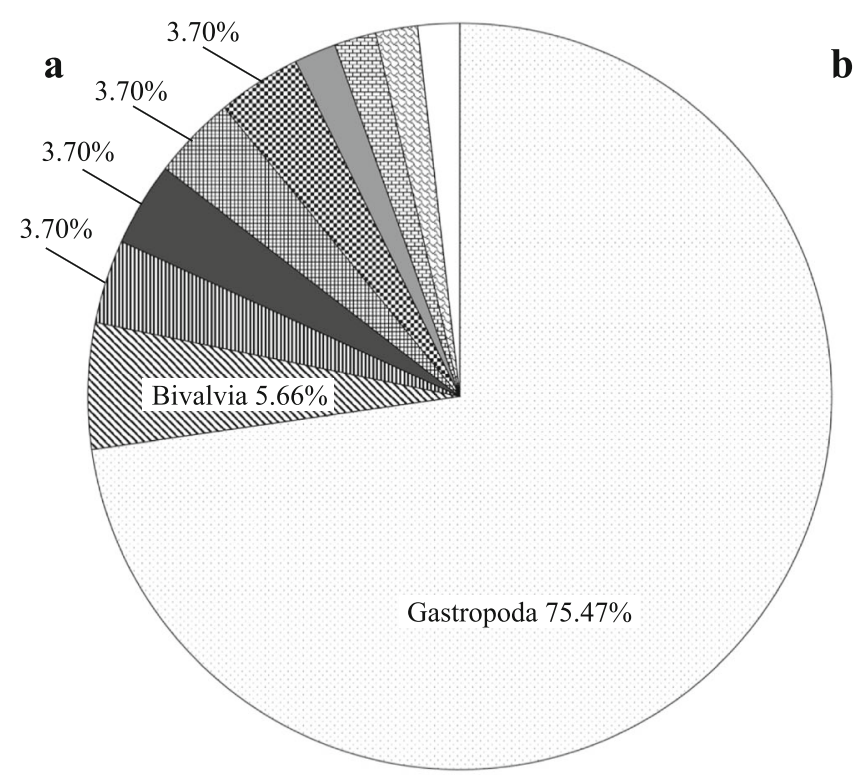

b

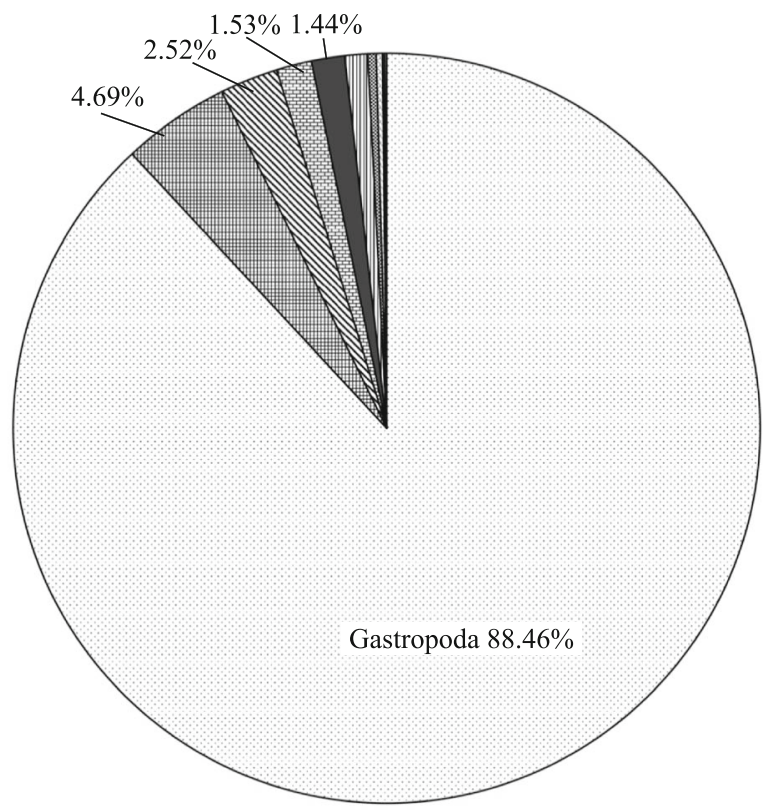

Gastropoda Bivalvia IIIIIII Rugosa

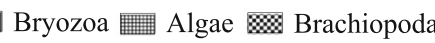
Scaphopoda 䜿 Porifera Crinoidea Polyplacophora

Fig. 8 a Pie chart of species composition and $\mathbf{b}$ abundance distributions of the studied samples, showing a strong dominance of gastropods 
Table 3 A list of all Thailand gastropod species and their occurrences from three locations, the Tak Fa Formation, the Ratburi Limestone and the Khao Khad Formation (see Ketwetsuriya et al. 2016, 2020a, 2020b)

Species Tak Fa Ratburi Khao Khad

Euphemites graffhami

Euphemites sp.

Warthia cf. brevisinuata

Warthia cf. saundersi

Warthia cf. welleri

Warthia sp. 1

Warthia sp. 2

Warthia? sp. 3

Bellerophon erawanensis

Bellerophon sp. 1

Bellerophon sp. 2

Bellerophon? sp. 1

Bellerophon? sp. 2

Pharkidonotus khaonoiensis

Khumerspira thailandensis

Retispira khaophrikensis

Retispira lyelli

Discotropis? sp.

Euomphalus cf. pronodocarinatus

Euomphalus? sp.

Holopea? sp.

Porcellia magninodosa

Biarmeaspira mazaevi

Apachella thailandensis

Baylea? umbilicata

Worthenia? waterhousei

Worthenia cf. crenulunula

Worthenia humiligrada

Worthenia cf. pagoda

Worthenia sp.

Altotomaria reticulata

Peruvispira sp. 1

Peruvispira sp. 2

Gosseletina microstriata

Eoplatyzona ratchaburiensis

Knightinella ornata

Knightinella sp.

Amaurotoma? multispirata

Amaurotoma? sp.

Hesperiella cyrtocostata

Takfaia kuesi

Ananias sp.

Glabrocingulum magnum

Ampezzalina? sp.

Anomphalus lateumbilicatus

Anomphalus cf. vanescens

Anomphalus? blancus

Tak Fa Ratburi Khao Khad

\section{$\bullet$}
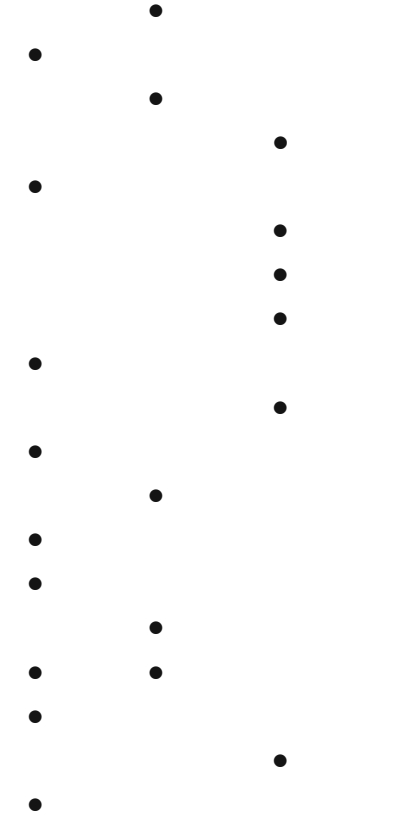

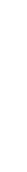

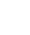

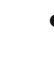

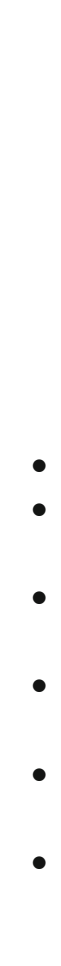

Table 3 (continued)

\begin{tabular}{llll}
\hline Species & Tak Fa & Ratburi & Khao Khad
\end{tabular}

Anomphalus sp.

Yunnania pulchra

Yunnania inflata

Anticonulus? sp.

Coeloconulus panae

Araeonema cf. tenuistriata

Eucycloscala cf. asiatica

Eocalliostoma sp.

Microdoma carinata

Microdoma conicum

Coeloconulus panae

Naticopsis spp.

Naticopsis sp. 1

Naticopsis sp. 2

Naticopsis sp. 3

Naticopsis? sp. 4

Naticopsis? sp. 5

Naticopsis cf. heshanensis

Trachydomia takhliensis

Trachydomia suwanneei

Trachydomia cf. nodosum

Trachyspira eleganta

Platyzona gradata

Goniasma tricarinata

Goniasma sp.

Stegocoelia centrosinuata

Stegocoelia sp. 1

Stegocoelia sp. 2

Stegocoelia? sp. 3

Stegocoelia? sp. 4

Procerithium? Inaequetuberculata

Orthonema sp.

Trypanocochlea lopburiensis

Chlorozyga asiatica

Hyphantozyga? khaophrikensis

Leptoptygma sp.

Soleniscus sp. 1

Soleniscus sp. 2

Soleniscus? sp. 3

Strobeus sp. 1

Strobeus? sp. 2

Strobeus? sp. 3

Girtyspira? sp.

Heterosubulites longusapertura

Cylindritopsis spheroides

Meekospira sp. 1

Meekospira? sp. 2

- $\quad$ Meekospira? sp. 3

Protostylus sp. 1 $\bullet$

-

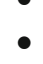

$\bullet$

-

-

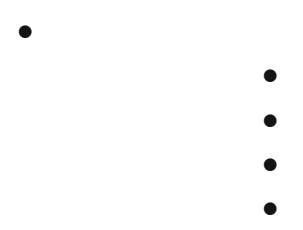

$\bullet$

$\bullet$

$\bullet$
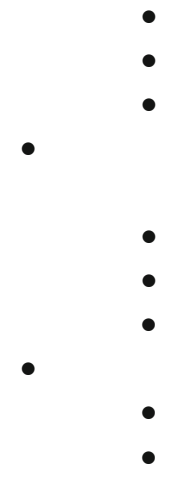

•

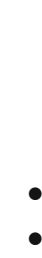


Table 3 (continued)

\begin{tabular}{|c|c|c|c|}
\hline Species & Tak Fa & Ratburi & Khao Khad \\
\hline Protostylus sp. 2 & & $\bullet$ & \\
\hline Protostylus sp. 3 & & & $\bullet$ \\
\hline Knightella irregularis & & & $\bullet$ \\
\hline Kimina sp. & & $\bullet$ & \\
\hline Ceraunocochlis sp. & $\bullet$ & & \\
\hline Cambodgia acuminata & $\bullet$ & & \\
\hline Palaeostylus sp. & & & $\bullet$ \\
\hline Palaeozygopleura cf. obesa & & $\bullet$ & \\
\hline Pseudozygopleura? sp. 1 & & & $\bullet$ \\
\hline Pseudozygopleura? sp. 2 & $\bullet$ & & \\
\hline Trepsipleura chordanodosa & $\bullet$ & & \\
\hline Donaldospira? sp. & & & $\bullet$ \\
\hline Streptacis? khaokhadensis & & & $\bullet$ \\
\hline Streptacis? sp. 1 & $\bullet$ & & \\
\hline Streptacis? sp. 2 & & $\bullet$ & \\
\hline Yoospira? sp. 1 & & $\bullet$ & \\
\hline Yoospira? sp. 2 & & $\bullet$ & \\
\hline Problematic uncoiled sinistral taxon & & $\bullet$ & \\
\hline Gen. indet. sp. Indet. 1 & & & $\bullet$ \\
\hline Gen. indet. sp. Indet. 2 & & & $\bullet$ \\
\hline
\end{tabular}

44 nominate species and 64 genera have been reported from three locations (Table 3), 34 as new species and also two new genera (Ketwetsuriya et al. 2016, 2020a, 2020b). Still, compared to brachiopod taxa reported from Southeast Asia (see Shi and Shen 2000), the number of gastropod occurrences is low. The high proportion of newly discovered species in these gastropod assemblages reflects the poor sampling, and given the vast amount of Permian calcareous rocks in Thailand and other areas of Southeast Asia, many of them lacking any palaeontological study, we anticipate many new discoveries in this region. In addition, 73 species have been reported in open nomenclature, reflecting the preservation of these gastropods - probably many of them could have been described as new if the preservation was sufficient. Most of the genera present in the Permian of Thailand are typical Late Palaeozoic genera with a widespread or even cosmopolitan distribution.

With 40 species, the studied gastropod assemblage from the Tak Fa Limestone in the Nakhon Sawan area, Central Thailand, is relatively rich when compared with other Permian gastropod faunas from Southeast and East Asia. Vetigastropoda are the most abundant and diverse group among the assemblage with the strong dominance of the species Anomphalus sp.. This limestone was situated in the Equatorial Warm Water Province of the Palaeo-Tethys (Metcalfe and Sone 2008), and the depositional environment was interpreted as a tropical shallow marine environment in the back reef on a restricted carbonate platform (Wielchowsky and Young 1985; Jaiboon 2001; Ketwetsuriya 2016).

Batten $(1972,1979,1985)$ reported 93 Permian gastropod species from limestones at Lee Mine, Perak, Malaysia, which derived from the Sibumasu Terrane (Tsegab et al. 2017). This gastropod fauna yielded bellerophontids, euomphalids, pleurotomarians, trochids, patellids, neritids, murchisoniids, cerithiids, loxonematids and subulitids. The age of this limestone is late Early Permian (Kungurian). This gastropod assemblage is dominated by the high-spired caenogastropods of which Omphaloptychia paleozoica is the most abundant species. Vetigastropods are as diverse as caenogastropods. The genera Glabrocingulum, Anomphalus and Apachella are the
Fig. 9 Rarefaction curves of the studied Middle Permian gastropod assemblage from the Tak Fa Limestone, Thailand, the Middle Permian gastropod assemblage from Perak, Malaysia (Batten 1972, 1979, 1985), the Middle Permian gastropod fauna from the Akasaka Limestone, Japan (Nützel and Nakazawa 2012), and the Permian gastropod fauna from Timor (Wanner 1941)

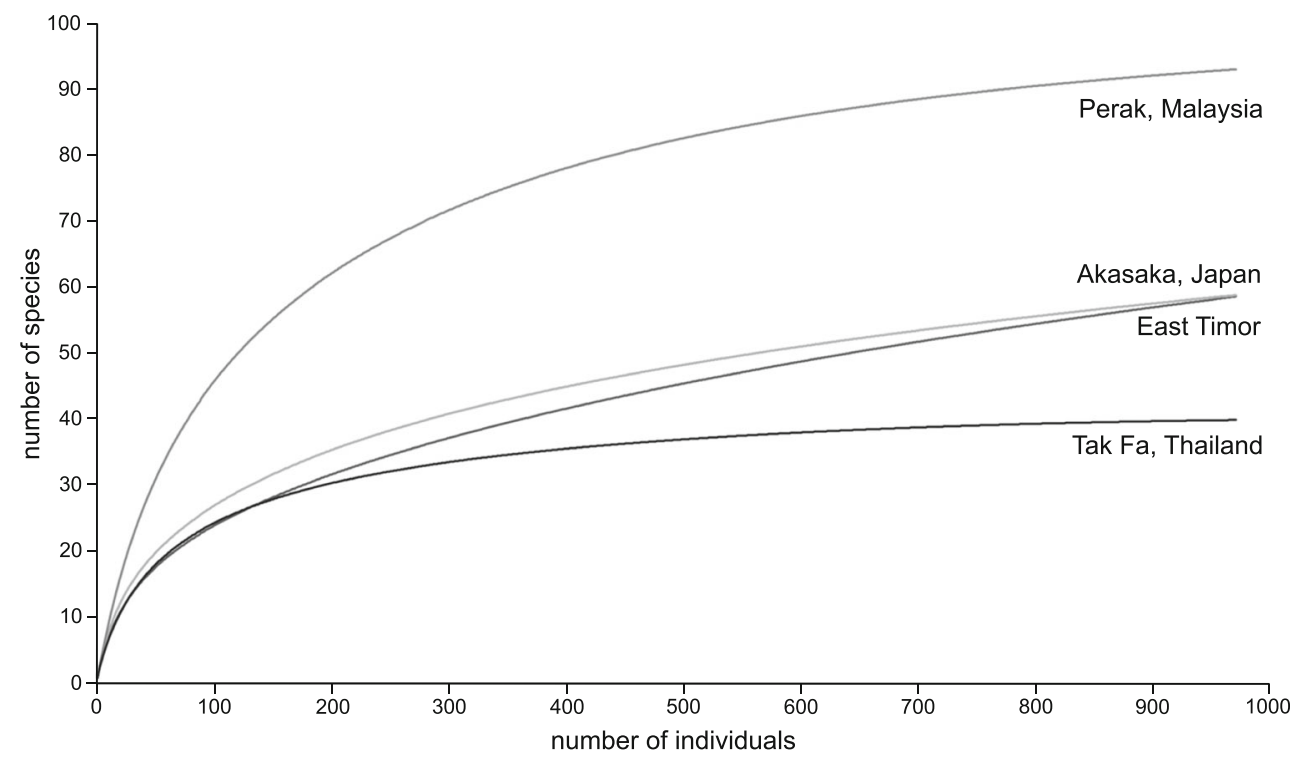


Table 4 Comparison of the diversity indices between the studied gastropod assemblage from the Tak Fa Limestone, Thailand, the gastropod assemblage from Perak, Malaysia (Batten 1972, 1979, 1985), the gastropod fauna from the Akasaka Limestone, Japan (Nützel and Nakazawa 2012), and the gastropod fauna from Timor (Wanner 1941)

\begin{tabular}{lllll}
\hline Samples & Species & Specimens & Simpson & Shannon Wiener \\
\hline Tak Fa, Thailand & 40 & 981 & 0.86 & 2.72 \\
Perak, Malaysia & 93 & 970 & 0.97 & 3.98 \\
Akasaka, Japan & 74 & 2263 & 0.93 & 3.13 \\
Timor & 67 & 1396 & 0.90 & 2.86 \\
\hline
\end{tabular}

most abundant vetigastropods. The bellerophontoideans comprise mostly the typical Middle to Late Palaeozoic genus Bellerophon. Neritimorpha are the mostly present with the genus Trachydomia. The gastropod fauna from Perak, Malaysia, is very diverse and has major implications for the palaeobiogeography at the margin of the eastern PalaeoTethys.

Wanner (1941) reported 67 species of Permian gastropods from East Timor with planispiral euomphalid shells being the most abundant. Bellerophontoideans make up the second most abundant group and are dominated by the genus Bellerophon. Other typical Late Palaeozoic genera such as Naticopsis, Trachydomia and Soleniscus are rare in the Timor fauna. This limestone was deposited in an open shallow marine environment in the Palaeo-Tethys.

Rich Permian gastropod fauna has been reported from Japan. Nützel and Nakazawa (2012) studied a very diverse Permian (Capitanian) gastropod fauna from the Akasaka Limestone (Gifu Prefecture, Japan). The Akasaka gastropod fauna comprises at least 74 species. The Akasaka Limestone is dominated by packstones with dark grey colour that were deposited in an open shallow marine environment on a palaeo-seamount in the Panthalassa Ocean (Ozawa and Nishiwaki 1992). The invertebrate fauna is strongly dominated by gastropods and bivalves (Koizumi 1995; Nakazawa 2007; Nützel and Nakazawa 2012). Caenogastropoda are the most abundant and diverse group among the gastropods. The Akasaka gastropod fauna shows relationships to faunas from China, Malaysia and Vietnam but contains also many formation singletons at species level.

The gastropod faunas from Malaysia, Japan and Thailand derive from fossil assemblages from tropical fusulinid limestones and hence were deposited under similar conditions as the Tak Fa fauna, which are tropical shallow carbonate platforms. In all three cases, gastropods are dominating the macro-fauna (Batten 1972; Koizumi 1995; Nützel and Nakazawa 2012). Therefore, in all these cases, gastropod diversity represents a comparable proxy for the diversity of entire macro-fauna.

The comparison of the present Tak Fa fauna with three other reported gastropod assemblages in Asia shows that the diversity of the Tak Fa fauna is relatively low and distinctly less diverse than the gastropod fauna from Malaysia, Timor and Japan according to rarefaction curves (Fig. 9) and diversity indices (Table 4). The Perak fauna has the highest diversity; diversity measures such as the Simpson Index of 0.97 (close to 1) and Shannon-Wiener Index of 3.98 (Table 4) indicate a very high diversity. Rarefaction analysis and diversity indices indicate that the Akasaka fauna is as diverse as the Timor fauna and that both significantly exceed the diversity of the studied Tak Fa fauna. Rarefaction curves of both assemblages are not yet fully saturated; therefore, additional sampling would result in finding additional taxa.
Fig. 10 Rank abundance diagram of the studied Middle Permian gastropod assemblage from the Tak Fa Limestone, Thailand, and other Permian gastropod assemblage from Asia

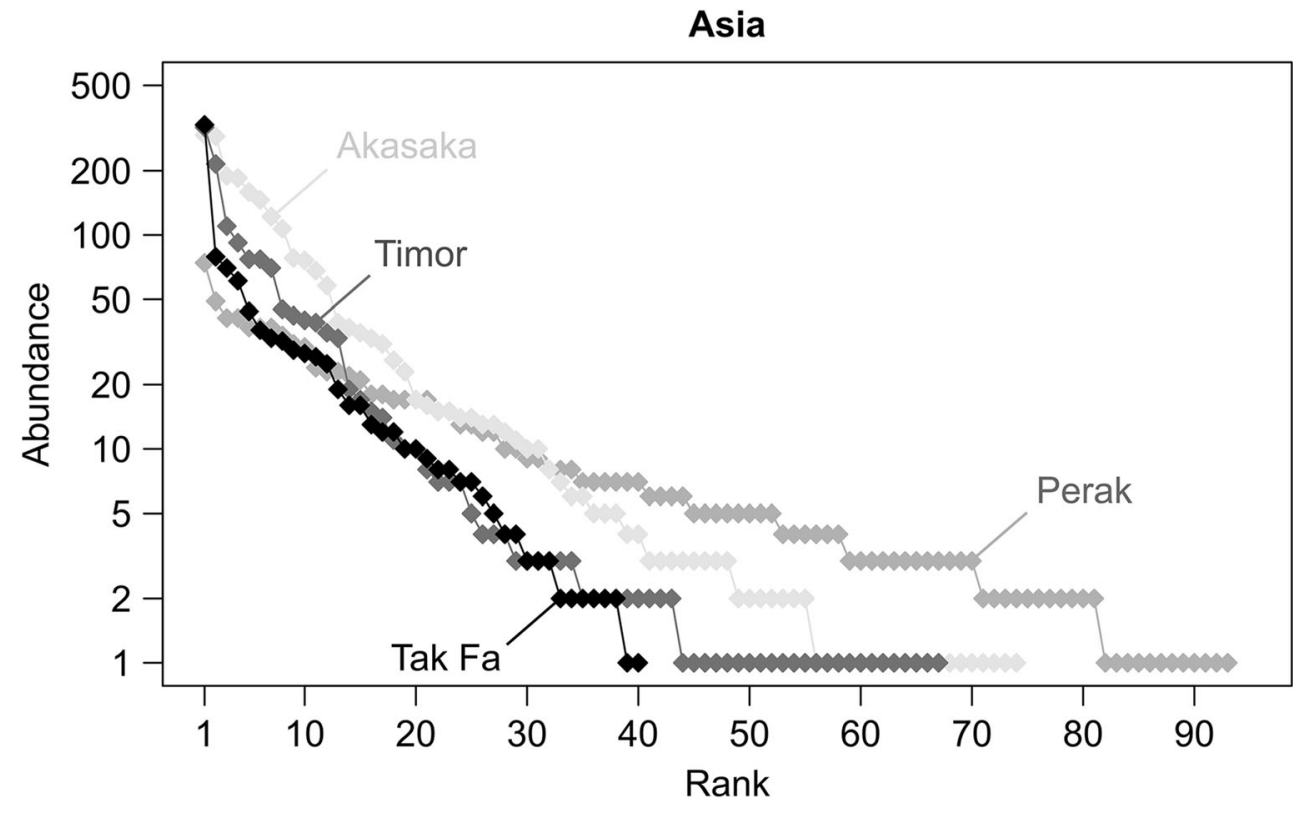


Table 5 Model fit for rank-abundance distributions of the Asian assemblages

\begin{tabular}{|c|c|c|}
\hline Asian assemblages & Models & AIC \\
\hline \multirow[t]{5}{*}{ Tak Fa, Thailand } & Brokenstick & 570.59 \\
\hline & Preemption & 473.38 \\
\hline & Lognormal & 225.33 \\
\hline & Zipf & 239.35 \\
\hline & Zipf-Mandelbrot & 241.35 \\
\hline \multirow[t]{5}{*}{ Perak, Malaysia } & Brokenstick & 390.13 \\
\hline & Preemption & 374.80 \\
\hline & Lognormal & 368.10 \\
\hline & Zipf & 474.13 \\
\hline & Zipf-Mandelbrot & 355.57 \\
\hline \multirow[t]{5}{*}{ Akasaka, Japan } & Brokenstick & 1539.06 \\
\hline & Preemption & 430.78 \\
\hline & Lognormal & 576.31 \\
\hline & Zipf & 922.08 \\
\hline & Zipf-Mandelbrot & 312.15 \\
\hline \multirow[t]{5}{*}{ Timor, East Timor } & Brokenstick & 1276.78 \\
\hline & Preemption & 480.55 \\
\hline & Lognormal & 325.98 \\
\hline & Zipf & 444.97 \\
\hline & Zipf-Mandelbrot & 278.37 \\
\hline
\end{tabular}

Best model fit is shown in bold. Both Tak Fa assemblages are pooled in this analysis

When fitting models to the rank-abundance distributions of Perak (Malaysia), Akasaka (Japan) and Timor (East Timor) (Fig. 10), they all fit best to the Zipf-Mandelbrot model (Table 5). In contrast, the Tak Fa fauna resembles mostly the lognormal distribution. This indicates differences in ecological processes (e.g. Wilson 1991; Magurran 2004) effective in the Tak Fa fauna compared to the other investigated Asian gastropod assemblages. Assemblages fitting the ZipfMandelbrot model are assumed to be shaped by ecological processes operating successively, whereas assemblages fitting best a lognormal distribution are thought to be characterised by simultaneously operating processes (e.g. Frontier 1985; Wilson 1991; Magurran 2004). For example, species interactions are one of the ecological processes and play together with physical pre-conditions a significant role in structuring successional stages of an assemblage that is described by the Zipf-Mandelbrot model; pioneer species and species which arrive later in a habitat are characterised by different requirements, resulting in a rare abundance of later immigrating species compared to pioneer species (e.g. Frontier 1985, 1987; Wilson 1991). However, since the ecological applicability of rank-abundance models is controversial and the question arises if model assumptions fit for all kind of assemblages (for instance, plants, invertebrates, vertebrates), an ecological interpretation should be drawn with caution (e.g. Magurran 2004). The shape of the rank-abundance distributions shows that the Perak assemblage has the highest evenness of all four assemblages. The second most even assemblage - following rank-abundance shape - is that from Akasaka (Japan). The assemblage with the lowest evenness is the one from the Tak Fa Limestone.

In terms of taxonomic composition, the Perak fauna (Malaysia) is dominated by caenogastropods. This is in contrast to the Tak Fa fauna in which vetigastropods form the most abundant group. Anomphalus sp., the most abundant gastropod from the Tak Fa fauna, is also present at Perak, and only a single species, Retispira lyelli (Gemmellaro 1890), is shared. Several typical Late Palaeozoic genera such as Bellerophon, Anomphalus, Glabrocingulum, Naticopsis, Trachydomia, Goniasma, Pseudozygopleura?, Meekospira?, Orthonema, Soleniscus, Cylindritopsis and Streptacis are present in both faunas. The genus Takfaia from the Tak Fa Limestone resembles the genus Ambozone Batten 1972 from Perak, Malaysia, and both genera are probably closely related to each other.

The Akasaka fauna from Japan, high-spired caenogastropods play an important role in this fauna. Moreover, Coeloconulus panae, one of the most abundant species from the Akasaka Limestone is present with a single specimen in the Tak Fa assemblage. The Akasaka fauna differs considerably in taxonomic composition from the Tak Fa fauna from Thailand. The vertigastropod Anomphalus sp. contributes $33.4 \%$ of the abundance of the Tak Fa fauna; conversely, it accounts for only $1.6 \%$ of the Akasaka fauna.

The Permian gastropod from East Timor is dominated by planispiral shells of an euomphalid species which contribute almost $30 \%$ to the total assemblage, but they are absent in the Tak Fa fauna. Bellerophontoideans make up the second most abundant group in Timor and are dominated by the genus Bellerophon, whereas Warthia is the most abundant bellerophontoid in the Tak Fa assemblage. The vetigastropod Anomphalus sp. is the most abundant gastropod of the Tak Fa fauna, but Anomphalus is present with only a single specimen in the Timor fauna. In addition, typical Late Palaeozoic genera are rare in the Timor fauna but abundant in Thailand.

High-spired caenogastropods are the most diverse and abundant group in the Akasaka Limestone as well as in the Perak fauna. Euomphalids are of minor importance in the mentioned Permian gastropod assemblages from Akasaka and Perak but are abundant in the Timor fauna. Although rarefaction analysis (Fig. 9) and diversity indices of the Timor fauna (Table 4) reveal the same curve patterns and the same diversity indices as the Akasaka fauna, the Timor fauna differs strongly in taxonomic composition (there are no shared species and few genera are shared). The taxonomic composition of the gastropod fauna from Timor differs also significantly from those of the Akasaka fauna (Japan), from the Tak Fa fauna (Thailand) and from the Perak fauna 
Table 6 A list of all Thailand Permian gastropod genera and their distribution in the Palaeo-Tethys

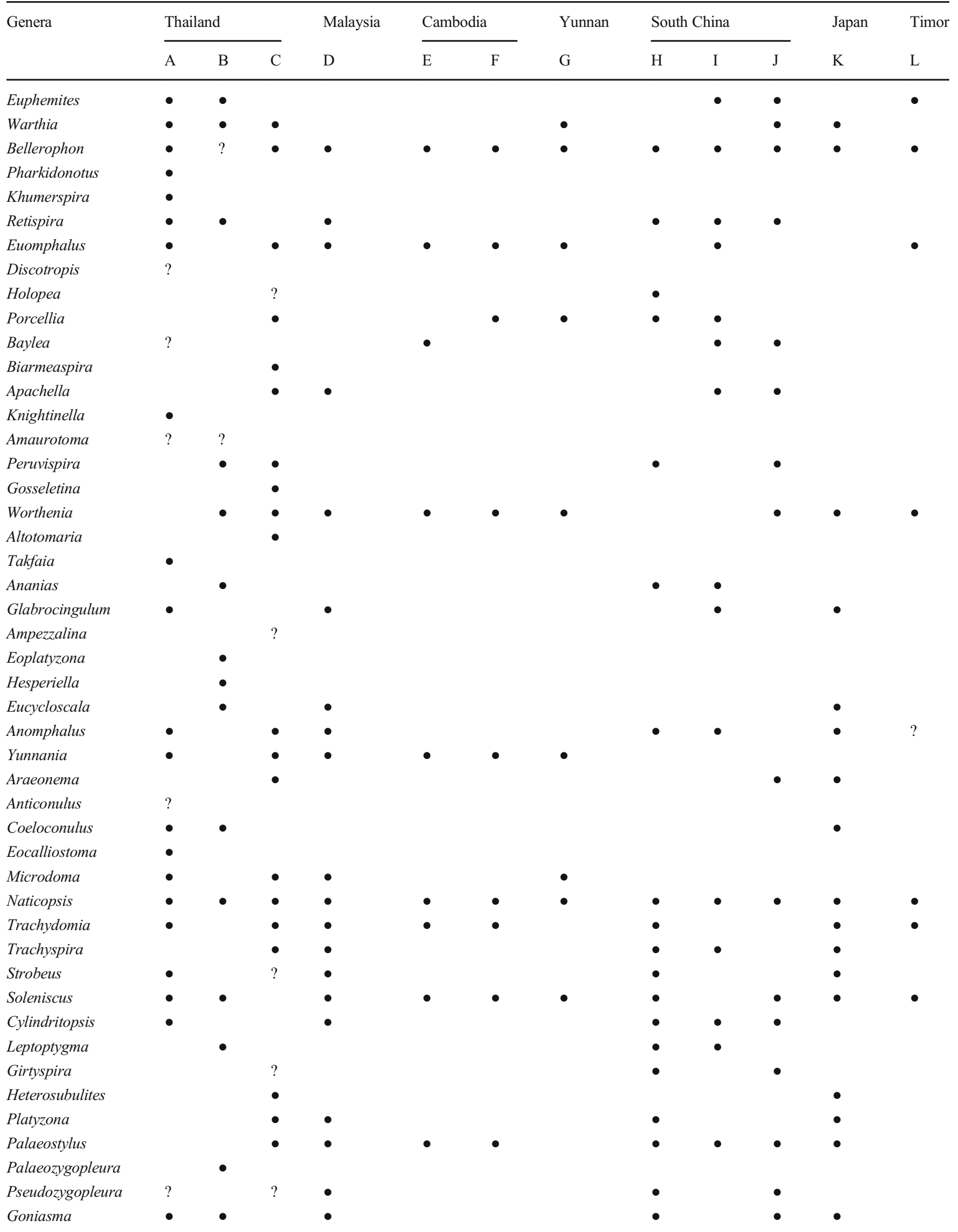


Table 6 (continued)

\begin{tabular}{|c|c|c|c|c|c|c|c|c|c|c|c|c|}
\hline \multirow[t]{2}{*}{ Genera } & \multicolumn{3}{|c|}{ Thailand } & \multirow{2}{*}{$\begin{array}{l}\text { Malaysia } \\
\text { D }\end{array}$} & \multicolumn{2}{|c|}{ Cambodia } & \multirow{2}{*}{$\begin{array}{l}\text { Yunnan } \\
\text { G }\end{array}$} & \multicolumn{3}{|c|}{ South China } & \multirow{2}{*}{$\begin{array}{l}\text { Japan } \\
\mathrm{K}\end{array}$} & \multirow{2}{*}{$\begin{array}{l}\text { Timor } \\
\mathrm{L}\end{array}$} \\
\hline & A & $\mathrm{B}$ & $\mathrm{C}$ & & $\mathrm{E}$ & $\mathrm{F}$ & & $\mathrm{H}$ & I & $\mathrm{J}$ & & \\
\hline Stegocoelia & $\bullet$ & $?$ & & $\bullet$ & & & & $\bullet$ & & & $\bullet$ & \\
\hline Orthonema & $\bullet$ & & & $\bullet$ & $\bullet$ & $\bullet$ & & & & $\bullet$ & $\bullet$ & \\
\hline Procerithium & & $?$ & & & & & & & & & & \\
\hline Hyphantozyga & & $?$ & & & & & & & & & & \\
\hline Chlorozyga & & $\bullet$ & & & & & & & & & & \\
\hline Cambodgia & $\bullet$ & & & & $\bullet$ & $\bullet$ & & & & & & \\
\hline Meekospira & $\bullet$ & $?$ & & $\bullet$ & & & & $\bullet$ & & & & \\
\hline Trepsipleura & $\bullet$ & & & & & & & & & & & \\
\hline Ceraunocochlis & $\bullet$ & & & $\bullet$ & & & & & & & $\bullet$ & \\
\hline \multicolumn{13}{|l|}{ Kimina } \\
\hline Donaldospira & & & $?$ & $\bullet$ & & & & & & & & \\
\hline Knightella & & & $\bullet$ & & & & & & & $\bullet$ & $\bullet$ & \\
\hline Protostylus & $\bullet$ & $\bullet$ & $\bullet$ & $\bullet$ & $\bullet$ & & & & & $\bullet$ & $\bullet$ & \\
\hline Trypanocochlea & & & $\bullet$ & & & & & & & & $\bullet$ & \\
\hline Streptacis & $?$ & $?$ & $?$ & $\bullet$ & & & & $\bullet$ & & & $\bullet$ & \\
\hline Yoospira & & $?$ & & & & & & & & & & \\
\hline
\end{tabular}

- present; ? present with uncertain generic placement. Locations: $A$, the present studied fauna; Tak Fa Formation, Nakhon Sawan, Thailand, Middle Permian (Ketwetsuriya et al. 2016); B, Ratburi Limestone, Ratchaburi, Thailand, Middle Permian (Ketwetsuriya et al. 2020a); $C$, Khao Khad Formation, Lopburi, Thailand, Middle Permian (Ketwetsuriya et al. 2020b); D, Perak, Malaysia, Middle Permian (Batten 1972, 1979, 1985); E, Cambodia, Middle Permian (Mansuy 1914); F, Sisophon Formation, Cambodia, Middle Permian (Delpey 1941); G, Yunnan, South China, Middle Permian (Mansuy 1912); H, Guangxi and Yunan, South China, Early-Late Permian (Pan and Erwin 2002); I, China, , Early-Late Permian (Pan and Yu 1993); J, Western Guizhou, South China, Late Permian (Wang and Xi 1980); K, Akasaka Limestone, Japan (Nützel and Nakazawa 2012); L, Timor, Middle Permian (Wanner 1941)

(Malaysia). Heterobranchia seems to be less important in all assemblages of Asia. However, protoconch preservation is needed to substantiate heterostrophy, and this preservation is either absent or rare in the compared assemblages due to insufficient preservation.

The gastropod fauna of the Tak Fa Limestone shares several taxa with Permian gastropod faunas from China, e.g. from Guangxi and Yunnan provinces, South China (Pan and Erwin 2002) and from Cambodia, e.g. the Permian Productus Limestone (Mansuy 1914) and the Permian of Cambodia (Delpey 1941) (Table 6). Moreover, some taxa resemble those from the Permian of the USA (cf. Moore 1941; Hall 1858; Chronic 1952; Erwin 1988a, 1988b). However, these shared taxa are rather on generic than species level.

For the mentioned Late Palaeozoic examples including those from Southeast Asia, typical Late Palaeozoic gastropod genera such as Bellerophon, Anomphalus, Glabrocingulum, Naticopsis, Trachydomia, Goniasma and Meekospira are present throughout. Others of course are formation singletons, Takfaia (Thailand), Asamiella, Akasakiella, Costataenia, Yochelsonistylus, Permocerithium (Akasaka), Loxisonia, Acrospira and Sinuozyga (Perak, Malysia), and have not been reported from the diverse and well-studied Permian gastropods faunas of the North American continent or the western Tethys. They may indicate the presence of the eastern Tethys/western Panthalassa gastropod faunal provinces. The diversity and preservation of these gastropods from Thailand, collected from only a few spots, show the potential for further discoveries in the area.

The differences in diversity and species composition between the mentioned Permian gastropod assemblages from Asia result probably from differences in latitude (Fig. 11), in depositional environment, in age and also in sampling methods. Although these fossil assemblages were deposited under similar conditions, considering that all assemblages derived from tropical shallow marinecarbonate platforms of the eastern Palaeo-Tethys during the Permian period, but variations in environmental factors, such as temperature, salinity, oxygenation, or sediment characteristics (Roden et al. 2020), may be linked to the differences in composition. However, it is remarkable that the Perak fauna is significantly more diverse than that of the Tak Fa fauna although the latter lived at lower, palaeo-latitudes, more or less at the palaeo-equator (see Metcalfe and Sone 2008). The Tak Fa fauna lived in a back reef environment of a restricted carbonate platform of the Indochina Terrane situated closely to volcanic arc. This may 


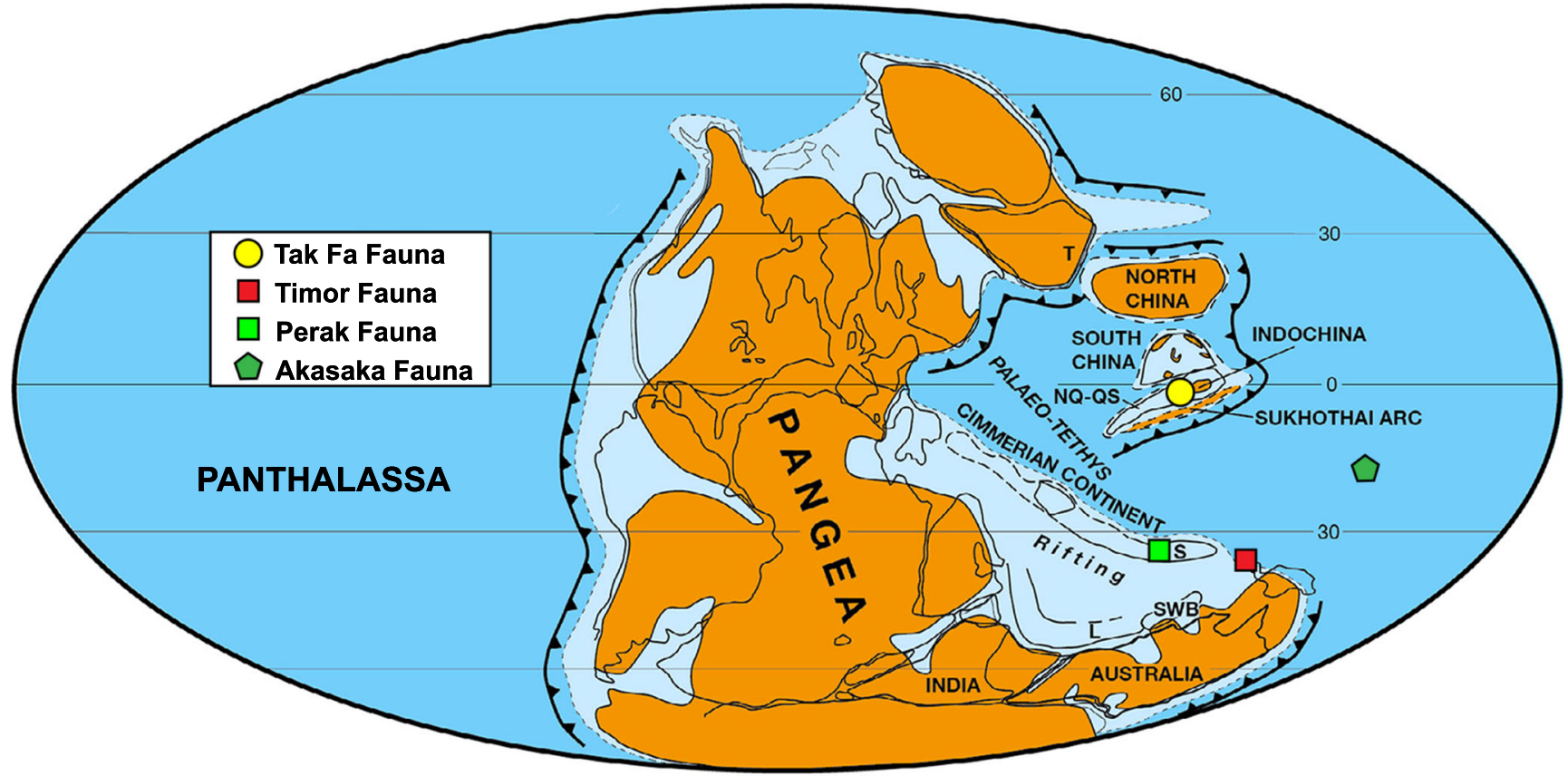

Land

Shallow Sea

Deep Sea

Fig. 11 Palaeogeographic map for the Middle Permian showing the geographic distribution of Middle Permian gastropods on the Indochina Terrane and the Cimmerian Continent during the Permian. S, Sibumasu; SWB, Borneo; NQ-QS = North Qiangtang-Qamdao-Simao (Modified from Metcalfe and Sone 2008)

have had a limiting impact on its diversity. However, other faunas lived in an open shallow marine environment. The comparison of the Tak Fa assemblage (close to palaeoequator) with assemblage from higher latitudes could suggest an inverse diversity gradient of Permian gastropods in the Palaeo-Tethys, i.e. diversity declines towards the equator. Powell (2009) found a shift of peak brachiopod diversity from South to North during the Phanerozoic; during the Late Palaeozoic, he observed maximum brachiopod diversity at about the palaeo-equator, but a slight shift to higher latitudes has occurred during Middle to Late Permian times.

The strong gastropod dominance of the Tak Fa fossil assemblage is remarkable because mollusc and gastropod dominance have been identified as being typical of the modern evolutionary fauna, but molluscs were by far not as important in the Palaeozoic (e.g. Sepkoski 1981). However, Clapham and Bottjer (2007) showed that relative abundances of molluscs including gastropods increased considerably during the Permian (analysed data from the USA, Greece and China). Gastropods are the most abundant and most diverse group of invertebrates in the Permian faunas from Asia (Malaysia, Japan and Thailand) discussed herein. Batten (1985) mentioned that gastropods dominate the fossil assemblage from Perak, Malaysia, although abundances and species richness of the non-gastropods were not reported. Yancey and Stevens (1981) reported communities that are strongly dominated by gastropods from the Early Permian of Nevada and Utah. For the Middle Permian Akasaka Limestone, Japan, Koizumi (1995), Nakazawa (2007) and Nützel and Nakazawa (2012) reported that approximately $55 \%$ of the species belong to Gastropoda. In the Permian faunas from Thailand, gastropods form the most diverse and abundant constituent. Seuss et al. (2009) showed that the fauna of the Pennsylvanian Buckhorn Asphalt Deposit (Pennsylvanian, USA) - one of the very few Palaeozoic assemblages with aragonitic shell material preserved - is dominated by gastropods.

These examples show that Late Palaeozoic faunas can be dominated by gastropods, although of course not all faunas are dominated by gastropods. Generally, gastropod dominance occurred earlier than previously assumed. For the Late Triassic Cassian Formation, Hausmann and Nützel (2015) and Roden et al. (2020) showed a pronounced mollusc dominance with gastropod being the most abundant and diverse group. This study and our results suggest that mollusc and gastropod dominance date back at least to the Late Palaeozoic/Early Mesozoic and that the apparent lack or scarcity of molluscs in many fossil assemblages is commonly result of taphonomic bias such as strong lithification or aragonite dissolution.

Acknowledgements The first author was supported by the Royal Thai Government who provided funding for a scholarship in the frame of the Development and Promotion of Science and Technology Talented Project. We thank Simon Schneider (Cambridge) and Andrzej Kaim (Warszawa) for reviewing this article and for their helpful comments. We are grateful to Pitsanupong Kanjanapayont for information on the 
geology of Thailand and for his support during the preparation of fieldwork. We would also like to thank Suwannee Phomprasith, Chawisa Phujareanchaiwon, Chittchon Chittpayak, Watcharapol Seeyangnok and students from Department of Geology, Faculty of Science, Chulalongkorn University for their help with field sampling. SNSBBayerische Staatssammlung für Paläontologie und Geologie is thanked for financial support.

Funding Open Acess funding enable and organized by Projekt DEAL.

\section{Declarations}

Conflict of Interest The authors declare that they have no conflict of interest.

Open Access This article is licensed under a Creative Commons Attribution 4.0 International License, which permits use, sharing, adaptation, distribution and reproduction in any medium or format, as long as you give appropriate credit to the original author(s) and the source, provide a link to the Creative Commons licence, and indicate if changes were made. The images or other third party material in this article are included in the article's Creative Commons licence, unless indicated otherwise in a credit line to the material. If material is not included in the article's Creative Commons licence and your intended use is not permitted by statutory regulation or exceeds the permitted use, you will need to obtain permission directly from the copyright holder. To view a copy of this licence, visit http://creativecommons.org/licenses/by/4.0/.

\section{References}

Batten, R. L. (1972). Permian gastropods and chitons from Perak, Malaysia. Part 1. Chitons, bellerophontids, euomphalids and pleurotomarians. Bulletin of the American Museum of Natural History, 147, 1-44.

Batten, R. L. (1979). Permian gastropods from Perak, Malaysia. Part 2. The trochids, patellids, and neritids. American Museum Novitates, $2685,1-26$.

Batten, R. L. (1985). Permian gastropods from Perak, Malaysia. Part 3. The murchisoniids, cerithiids, loxonematids, and subulitids. American Museum Novitates, 2829, 1-40.

Chitnarin, A., Crasquin, S., Charoentitirat, T., Tepnarong, P., \& Thanee, N. (2012). Ostracods (Crustacea) of the Early- Middle Permian from Central Thailand (Indochina block). Part I. Order Palaeocopida. Geodiversitas, 34(4), 801-835.

Chitnarin, A., Crasquin, S., Forel, M.-B., \& Tepnarong, P. (2017). Ostracods (Crustacea) of the Early-Middle Permian (CisarulianGuadalupian) from Central Thailand (Indochina Block): Part II, Orders Podocopida, Platycopida and Myodocopida. Geodiversitas, 39(4), 651-690.

Chonglakmani, C. \& Fontaine, H. (1992). The Lam Narai-Phetchabun region: A platform of Early Carboniferous to Late Permian age. In P. Charusiri, s. Jarupongsakul \& V, Pisutha-arnond (Eds.), Proceeding of the Technical Conference on Development of Geology for Thailand into the year 2000 (pp. 39-98). Bangkok: Chulalongkorn University, Thailand.

Chronic, H. (1952). Molluscan fauna from the Permian Kaibab Formation, Walnut Canon, Arizona. Bulletin of the Geological Society of America, 63, 95-166.

Clapham, M. E., \& Bottjer, D. (2007). Permian marine paleoecology and its implications for large-scale decoupling of brachiopod and bivalve abundance and diversity during the Lopingian (Late Permian).
Palaeogeography, Palaeoclimatology, Palaeoecology, 249, 283301.

Delpey, G. (1941). Les Gastéropodes permiens du Cambodge. Journal de Conchyologie, 84(255-278), 345-369.

Erwin, D. H. (1988a). Permian Gastropoda of the Southwestern United States: Cerithiacea, Acteonacea, and Pyramidellacea. Journal of Paleontology, 62, 566-575.

Erwin, D. H. (1988b). Permian Gastropoda of the Southwestern United States: Subulitacea. Journal of Paleontology, 62, 56-69.

Fontaine, H., Salyapongse, S., \& Vachard, D. (1999). Fossils from Khao Sak and the adjacent hills, Amphoe Chon Daen, central Thailand. CCOP Newsletter, 24(1), 9-14.

Frontier, S. (1985). Diversity and structure in aquatic ecosystems. In M. Barnes (Ed.), Oceanography and Marine Biology - An Annual Review (pp. 253-312). Aberdeen: Aberdeen University Press.

Frontier, S. (1987). Applications of fractal theory to ecology. In P. Legendre \& L. Legendre (Eds.) Develoments in Numerical Ecology. NATO ASI Series (Series G: Ecological Sciences), vol 14. (pp. 335-378). Berlin, Heidelberg: Springer.

Gemmellaro, G. G. (1890). La Fauna dei calcari con Fusulina della valle del fiume Sosio nella Provincia di Palermo. Giornale di Science Naturali ed Economiche, 20, 97-182.

Grant, R. E. (1976). Permian brachiopods from southern Thailand. Paleontological Society Memoir, 9, 1-269.

Hall, J. (1858). Description of new species and fossils from the Carboniferous limestones of Indiana and Illinois. Transactions of the Albany Institute, 4, 1-36.

Hammer, Ø., Harper, D. A. T., \& Ryan, P. D. (2001). PAST: Palaeontological statistics software package for education and data analysis. Palaeontologia Electronica, 4(1), 1-9.

Hausmann, I., \& Nützel, A. (2015). Diversity and palaeoecology of a highly diverse Late Triassic marine biota from the Cassian Formation at the Stuores Wiesen (North Italy, Dolomites). Lethaia, 48, 235-255.

Igo, H. (1972). Fusulinacean fossils from Thailand. Part VI. Fusulinacean fossils from North Thailand. In T. Kobayashi \& R. Toriyama (Eds.), Geology and Palaeontology of Southeast Asia (pp. 63-116). Tokyo: University of Tokyo Press.

Igo, H. (1992). Orientoschwagerina (Fusulinacea) from Khao Tham Rusi, south of Lom Sak, central Thailand. Annual Report of the Institute of Geoscience, University of Tsukuba, No. 18, 43-47.

Jaiboon, T. (2001). Biostratigraphy of Tak Fa Formation at Khao Wong and Khao Chakkachan, Amphoe Hong Muang, Changwat Lop Buri with reference to Fusulinids. Master Thesis, Department of Geology, Faculty of Science, Chulalongkorn University, Bangkok, Thailand.

Ketwetsuriya, C. (2016). Biosystematics of Gastropoda fossil from Permian Tak Fa Formation, Amphoe Tak Fa and Amphoe Takhli, Changwat Nakhon Sawan. Master thesis, Department of Geology, Faculty of Science, Chulalongkorn University, Bangkok, Thailand.

Ketwetsuriya, C., Nützel, A., \& Kanjanapayont, P. (2014). A new Permian gastropod fauna from the Tak Fa Limestone, Nakhonsawan, Northern Thailand - a report of preliminary results. Zitteliana A, 54, 137-146.

Ketwetsuriya, C., Nützel, A., \& Kanjanapayont, P. (2016). Permian gastropods from the Tak Fa Limestone, Nakhon Sawan, Northern Thailand. Bulletin of Geosciences, 91, 481-513.

Ketwetsuriya, C., Cook, A. G., \& Nützel, A. (2020a). Permian gastropods from the Ratburi Limestone, Khao Phrik, Central Thailand. Paläontologische Zeitschrift, 94, 53-77. https://doi.org/10.1007/ s12542-019-00463-0.

Ketwetsuriya, C., Kampunar, B., Charoentitirat, T., \& Nützel, A. (2020b). Middle Permian (Roadian) gastropods from the Khao Khad Formation, Central Thailand: Implications for palaeogeography of the Indochina Terrane. Zootaxa, 4766(1), 1-47. 
Koizumi, S. (1995). Gastropoda. In K. Hachiya (Ed.), The illustrated collections of Asami Fossil Museum, Fossils of Kinsyozan (pp. 95-169). Asami Fossil Museum: Gifu. [in Japanese]

Kues, B. S. (2002). New genera and species of Middle Pennsylvanian gastropods from west Texas. Journal of Paleontology, 76(1), 52-62.

Magurran, A. E. (2004). Measuring Biological Diversity. Malden: Blackwell Publishing.

Mansuy, H. (1912). Étude Géologique du Yun-Nan Oriental. In: J. Deprat, \& H. Mansuy (Eds.), Mémoires du Service Géologquie de l'Indochine, 1-146.

Mansuy, H. (1914). Nouvelle contribution à la paléontologie du Yunnan. Mémoires du Service Géologique de l'Indochine, 3(2), 1-190.

Metcalfe, I., \& Sone, M. (2008). Biostratigraphy and palaeobiogeography of Lower Permian (lower Kungurian) conodonts from the Tak Fa Formation (Saraburi Limestone), Thailand. Palaeogeography, Palaeoclimatology, Palaeoecology, 257, 139-151.

Moore, R. C. (1941). Upper Pennsylvanian gastropods from Kansas. State Geological Survey Kansas, Bulletin, 38, 121-164.

Nakazawa, K. (2007). Minute bivalve fossils from the Permian Akasaka Limestone, Central Japan: (Appendix) Description of a new species of Pernopecten. Earth Science, 61, 187-201. [in Japanese with English abstract and English description of new species]

Nakornsri, N. (1976). Geological Map of Ban Mi Sheet ND 47-4, Scale 1: 250,000, Geological Survey Division. Bangkok: Department of Mineral Resources, Thailand.

Nakornsri, N. (1981). Geology and Mineral Resources of Amphoe Ban Mi (ND 47-4), Geological Survey Report Number 3. Bangkok: Department of Mineral Resources, Thailand.

Napradit, T. (2005). Permian Fusulinoidean Limestones from East of Changwat Nakhon Sawan. Master Thesis, Department of Geology, Faculty of Science, Chulalongkorn University, Bangkok, Thailand.

Nützel, A., \& Nakazawa, K. (2012). Permian (Capitanian) gastropods from the Akasaka Limestone (Gifu Prefecture, Japan). Journal of Systematic Palaeontology, 10, 103-169.

Oksanen, J., Blanchet, F. G., Friendly, M., Kindt, R., Legendre, P., McGlinn, D., Minchin, P. R., O'Hara, R. B., Simpson, G. L., Solymos, P., Stevens, M. H. H., Szoecs, E. \& Wagner, H. (2018). vegan: Community Ecology Package. $\mathrm{R}$ package version 2.5-2. https://CRAN.R-project.org/package=vegan.

Ozawa, T., \& Nishiwaki, N. (1992). Permian Tethyan Biota and Sedimentary Facies of the Akasaka Limestone Group. Field Trip Guidebook of International Geological Congress, B13, 189-195.

Pan, H.-Z., \& Erwin, D. H. (2002). Gastropods from the Permian of Guangxi and Yunnan provinces, South China. Journal of Paleontology, 78, Supplement to No 1. The Paleontological Society Memoir, 56, 1-49.

Pitakpaivan, K. (1965). Fusulines of the Rat Buri limestone of Thailand. Memoirs of the Faculty of Science, Kyushu University, Series D, Geology, 17, 3-69.

Powell, M. (2009). The latitudinal diversity gradient of brachiopods over the past 530 million Years. The Journal of Geology, 117(6), 585594.

Prado, P. I., Miranda, M. D. \& Chalom, A. (2018). sads: Maximum likelihood models for species abundance distributions. R package version 0.4.2. https://CRAN.R-project.org/package=sads.

$\mathrm{R}$ Core Team. (2017). R: A language and environment for statistical computing. Vienna: R Foundation for Statistical Computing https://www.R-project.org/.

Roden, V. J., Hausmann, I. M., Nützel, A., Seuss, B., Reich, M., Urlichs, M., Hagdorn, H., \& Kiessling, W. (2020). Fossil liberation: a model to explain high biodiversity in the Triassic Cassian Formation. Palaeontology, 63, 85-102.
Sakagami, S. (1975). Permian bryozoan from Khao Hin Kling, near Phetchabun, North-central Thailand. In T. Kobayashi \& R. Toriyama (Eds.), Geology and Palaeontology of Southeast Asia (Vol. 16, pp. 33-43). Tokyo: University of Tokyo Press.

Sakagami, S. (1999). Permian bryozoans from some localities in the Khao Hin Kling area near Phetchabun, North-central Thailand. Bulletin of the Kitakyushu Museum of Natural History, 18, 77-103.

Sepkoski, J. J. (1981). A factor analytical description of the Phanerozoic marine fossil record. Paleobiology, 7, 36-53.

Seuss, B., Nützel, A., Mapes, R. H., \& Yancey, T. E. (2009). Facies and fauna of the Pennsylvanian Buckhorn Asphalt Quarry deposit: A review and new data on an important Palaeozoic fossil Lagerstätte with aragonite preservation. Facies, 55, 609-645.

Shi, G. R., \& Shen, S. (2000). Asian-Western Pacific Permian brachiopoda in space and time: biogeography and extinction patterns. In H. Yin, J. M. Dickins, G. R. Shi, \& T. Jinnan (Eds.), Permian-Triassic Evolution of Tethys and Western CircumPacific, Developments in Palaeontology and Stratigraphy (pp. 327-352).

Sone, M. (2010). A new species of the rare neritopsid gastropod Magnicapitatus from the Guadalupian (Middle Permian) of East Thailand (the Indochina Terrane). Alcheringa, 34, 1-6.

Sone, M., Chonglakmani, C., \& Chitnarin, A. (2009). Middle Permian Productidine Brachiopods from Central Thailand (the Indochina Terrane) with Paleobiogeographic Implications. Journal of Paleontology, 83(5), 804-810.

Tsegab, H., Sum, C. W., Yuriy, G. A., Hunter, A. W., Abtalib, J., \& Kassa, S. (2017). Higherresolution biostratigraphy for the Kinta Limestone and an implication for 1 continuous sedimentation in the Paleo-Tethys, Western Belt of Peninsular Malaysia. Turkish Journal of Earth Sciences, 26(5), 377-394.

Ueno, K., \& Charoentitirat, T. (2011). Carboniferous and Permian. In M. F. Rido, A. J. Barber, \& M. J. Crow (Eds.), The Geology of Thailand (pp. 71-135). London: Geological Society.

Wang, H. J., \& Xi, Y. H. (1980). Late Permian to Early Triassic gastropods from Western Guizhou Province. Stratigraphy and Palaeontology of Upper Permian Coal-bearing Formation in Western Guizhou and Eastern Yunnan, 1980, 195-240.

Wanner, C. (1941). Neue Beiträge zur Gastropoden fauna des Perm von Timor. In Geological Expedition to the Lesser Sunda Islands Under the leadership of H. A. Brouwer, Professor of Geology at the University of Amsterdam. Vol. 4. Nieuw Verbond NoordHollandsche Uitgevers Maatschappij (pp.1-71). Amsterdam.

Waterhouse, J. B. (1982). An Early Permian cool-water fauna from pebbly mudstones in south Thailand. Geological Magazine, 119, 337354.

Wielchowsky, C. C. \& Young, J. D. (1985). Regional facies variations in Permian rocks of the Phetchabun fold and thrust belt, Thailand. Conference on the Geology and Mineral Resource Development of NE Thailand, 41-55.

Wilson, J. B. (1991). Methods for fitting dominance/diversity curves. Journal of Vegetation Science, 2, 35-46.

Yanagida, J. (1988). Biostratigraphic Study of Paleozoic and Mesozoic Groups in central and northern Thailand. In J. Yanagida (Ed.), An Interim Report by the Research Group (pp. 1-47). Fukuoka: Department of Geology, Faculty of Science, Kyushu University.

Yancey, T. E., \& Stevens, C. H. (1981). Early Permian fossil communities in northwestern Nevada and northeastern Utah. In C. Gray, A. J. Boucot, \& W. B. N. Berry (Eds.), Communities of the past (pp. 243 269). Hutchinson: Stroudsburg.

Publisher's note Springer Nature remains neutral with regard to jurisdictional claims in published maps and institutional affiliations. 